Maurice A. Deane School of Law at Hofstra University Scholarly Commons at Hofstra Law

Hofstra Law Faculty Scholarship

2006

\title{
The Family Law Education Reform Project: Final Report
}

\author{
J. Herbie DiFonzo \\ Maurice A. Deane School of Law at Hofstra University \\ Mary E. O’Connell
}

Follow this and additional works at: https://scholarlycommons.law.hofstra.edu/faculty_scholarship

\section{Recommended Citation}

J. Herbie DiFonzo and Mary E. O'Connell, The Family Law Education Reform Project: Final Report, 44 Fam. Ct. Rev. 524 (2006) Available at: https://scholarlycommons.law.hofstra.edu/faculty_scholarship/209

This Article is brought to you for free and open access by Scholarly Commons at Hofstra Law. It has been accepted for inclusion in Hofstra Law Faculty Scholarship by an authorized administrator of Scholarly Commons at Hofstra Law. For more information, please contact lawcls@hofstra.edu. 


\title{
THE FAMILY LAW EDUCATION REFORM PROJECT FINAL REPORT
}

\author{
Mary E. O’Connell \\ J. Herbie DiFonzo ${ }^{1}$
}

\begin{abstract}
The Family Law Education Reform Project (the FLER Project) is co-sponsored by the Association of Family and Conciliation Courts and the Center for Children, Families and the Law at Hofstra Law School. This Final Report is based on a series of dialogues between family law academics and practitioners from many disciplines, a FLER Project survey, and research conducted by law students at Hofstra University and Northeastern University. ${ }^{2}$
\end{abstract}

Keywords: legal education; family law; FLER Project; interdisciplinary; alternative dispute resolution; lawyering; skills; pro se

\section{INTRODUCTION: WHY REFORM FAMILY LAW EDUCATION?}

The last two decades have seen substantial - even dramatic - changes in family law, most particularly in the ways in which family law is practiced. As this sea of change has occurred, however, law school curricula and teaching have remained relatively static. The result, predictably, is that lawyers entering family law practice regularly find themselves unprepared for what they encounter. A substantial and growing gap between family law teaching and family law practice undermines the best efforts of new family lawyers to assist parents and children in separation, divorce, abuse and neglect, dependency, and delinquency actions.

Today's family lawyers need a thorough understanding of many issues and practices that traditional family law courses rarely touch upon. These include the appropriate-and inappropriate - uses of dispute resolution processes, new case management techniques in the family courts, the key roles played by professionals from other disciplines in the court system, and current research on such issues as the effects of conflict and loss of parental contact on children. Yet the materials from which most family law professors teach contain nary a word on most of these topics or on the skills necessary for effective family law practice.

\section{A. ENTER THE FLER PROJECT}

The Family Law Education Reform Project (the FLER Project) was launched by a group of professionals who share a common concern. ${ }^{3}$ In their regular (for some, daily) interactions in the family court, they routinely observe lawyers who are woefully unprepared to make positive contributions on behalf of their clients. While some novice attorneys struggle valiantly and learn quickly, the quality of their initial preparation is, to use a term that surfaced often in FLER Project discussions, dismal. The question this group asked is "can we help the law schools to do this better?"

Correspondence: M.O'connell@neu.edu or lawjhd@hofstra.edu

FAMILY COURT REVIEW, Vol. 44 No. 4, October 2006 524-570

(C) 2006 Association of Family and Conciliation Courts 
Since the spring of 2004, scores of contributors from a range of disciplines have come together in various FLER Project sessions to think collectively - and rigorously - about what a new family lawyer should know, should be aware of, and should be competent to undertake. ${ }^{4}$ What emerged was a strongly shared sense that family law as it is presently taught in many American law schools bears only an attenuated relation to the family law that affects real people, the courts, and our larger society every day. To put it more bluntly: law schools are preparing students for something generically called "family law," but they are not (with a few notable exceptions) preparing students to deal with family law as it is practiced beyond the law schools' doors.

How might a family law curriculum prepare fledgling lawyers for the realities of contemporary practice?

(1) It would teach law students that the family court of the early twenty-first century is often an interdisciplinary enterprise, where psychologists, social workers, non-lawyer mediators, and others may wield extraordinary power. At times, these professionals may work as partners with the attorney, providing both help and insight in the resolution of a family dispute. In other cases, the attorney's role is to help the client navigate the often bewildering world of mandatory mediation, mandatory divorce education, court-appointed custody evaluation, parenting coordination, and more.

(2) It would emphasize the multiplicity of dispute resolution processes and treat litigation as but one alternative, useful only in a small minority of cases. Students would be introduced to mediation, mediation advocacy, collaborative law, cooperative law, and advanced techniques in negotiation. The burdens and benefits of each of these approaches would be evaluated, with the goal of enabling new lawyers to assist their clients in making informed choices among them.

(3) It would continue to emphasize strong grounding in the law and analytic rigor, but would add a focus on competence and skills, and teach budding lawyers to be reflective and self-aware in the practice of law. Students would be exposed to the paradox that, in this age of increasing legal specialization, a family law practice demands a quite broad-based expertise. To represent clients adequately, family lawyers must be knowledgeable in such fields as tax, contracts, ERISA, real estate, and health insurance continuation (COBRA), as well as family systems theory, child psychology, and family violence. Practitioners also need strong skills in interviewing, listening, and counseling emotionally troubled clients.

These goals are strongly consonant with views expressed in the American Law Institute's (ALI) Principles of the Law of Family Dissolution. ${ }^{6}$ The ALI Principles note that " $[\mathrm{t}] \mathrm{he}$ primary challenge in shaping the law that governs allocation of responsibility for children is to facilitate thoughtful planning by cooperative parents while minimizing harm to children who are caught in a cycle of conflict."7 Among the ALI Principles' stated goals are "to focus greater attention during family breakdown on planning for the child's needs; (2) locate responsibility for the child in parents, and in courts only as the last resort; ... (5) encourage parents to anticipate future problems and disputes and to establish means of resolving them short of reiteration in court; ... (7) provide appropriate protection for victims of domestic abuse after a family separation." ${ }^{\prime}$ These themes were raised and repeated in numerous, thoughtful ways throughout the FLER Project's working sessions.

\section{B. HAVE WE ASSUMED THE CONCLUSION?}

As we have prepared this Report, we have endeavored to avoid endorsing any particular approach to resolving family disputes. The question is significant: by inviting 
custody evaluators, mediators, parent educators, and others to the table, did we begin our task with the assumption that a model of family law that relies heavily on alternatives to litigation, and is strongly influenced by psychological theories and mental health professionals, is not only relatively new, but also greatly improved? Clearly, many of the FLER Project's participants strongly endorse the view that custody evaluators, mediators, and other professionals better the family law process for the men and women involved in family disputes and for their children. We would argue, however, that one can find useful ideas in this Report and its suggestions without concurring in that assertion. The Report is intended for believer and agnostic alike.

Whatever one may think of contemporary family courts' substantial reliance on psychological evaluations, social science research, and non-lawyer mediators, the reality is that this mental health/alternative dispute resolution (ADR) orientation strongly influences many courts and, at times, legislatures as well. ${ }^{9}$ Whether this emphasis proves to be too much, too little, or just enough is beyond the scope of this Report. The appropriate limits to the partnership between law and the social sciences are similarly a question for future consideration. Rather than endorsing any current or emerging model of family court administration or practice, we hope that the FLER Project will help law professors to equip new lawyers to meet family law where it is. Of course, our fondest hope is that the young lawyers we teach will not only meet family law, but work to bring it to a better place.

None of the suggestions in this Report would displace the central emphasis on analytic thinking that is a hallmark of all legal education. Students will and must continue to grapple with complex constitutional doctrine and challenging statutory language, but as all law professors know, those key tasks can be embedded in the course material in nearly endless ways. It is also our perception that law professors already carry out this task of teaching, modeling, and reinforcing strong analytic thinking, and they do it very well. The challenge this Report poses is to take family law beyond the analytic - not to leave the analytic behind - to pose additional and related problems arising from the reality of family law practice.

\section{THE FLER REPORT AND THE FLER PROJECT}

This Report is our effort, as the Project Reporters, to synthesize, order, and elaborate upon the insights of the lawyers, judges, mediators, psychologists, social workers, court administrators, law professors, and others who endorsed the conclusions listed above. To that end, we attempt to:

* Describe the divergence between family law in the classroom and family law in the courtroom, lawyer's office, conference room, and home;

* Outline and elaborate upon the areas that a family law curriculum should cover if its goal is to prepare students who are well versed in the law, sensitive to legal context, and competent to serve their clients in an ethical manner.

This Report, however, is only the beginning. The FLER Project's long-term and more ambitious goal is to create a set of interdisciplinary teaching modules. These modules (which will specifically identify learning objectives and suggest teaching strategies) will help law professors to integrate new topics, issues, and skills training into their family law courses. When the modules are completed, law faculty will be able to adopt, or adapt, one or more of them for use in their teaching, for their own information, or to suggest research projects for students. Our hope is that these modules, by providing insights and knowledge 
assembled by experts in a number of fields directly germane to contemporary family law practice, will enable our colleagues (and ourselves) to expand the scope of our current courses. As we attempt to assemble a family law curriculum attuned to twenty-first century practice, we will draw upon our colleagues' wide-ranging expertise and, through the modules, place it at the disposal of family law professors.

Finally, the FLER Project and this Report attempt to model the interdisciplinary collaboration that can effect meaningful change in family law education. Although this Report is primarily addressed to law professors, we hope to solicit the endorsement and participation of other constituencies, such as law school administrators, the courts, bar examiners, foundations, and other professionals with an interest in the law's impact on families. All those concerned with family law have something to contribute to a project whose goal is making the teaching of family law more consonant with the reality of family law practice.

This Report is organized as follows: Section II provides a status report on contemporary family law teaching. Section III, "Teaching the Four C's," urges that the family law curriculum, already strong in Content, could be productively organized to stress three additional major concepts: Context, Conduct, and Competence. Our Conclusion includes a set of recommendations and our assessment of the next steps required in this process.

\section{WHERE ARE WE NOW IN FAMILY LAW TEACHING?}

The FLER Project has been driven by the conviction that law students need greater exposure to the central role of ADR processes in family law and to the interdisciplinary nature of much of contemporary family law practice. However, although we believe that process has driven substance in the family law of the past few decades, there is no doubt that substantive law remains at the core of legal education. A major task of family law professors is to introduce students to a body of law consisting of seminal cases, sample statutes, and regulations. Taken together, these legal building blocks form the basic architecture within which the practice of family law occurs and the rights and obligations of adults and children in relationships are constructed. Legal historian Michael Grossberg has reminded us that "contemporary family law disputes, like those of the past, demonstrate again and again the ordering power of the law." 10

Law teaching is a diverse and idiosyncratic craft, driven largely by the insights and expertise of individual faculty members. The flexibility and autonomy most law professors enjoy allow them to pursue their unique scholarly agendas and to enrich, challenge, and at times, transform the law. But the decentralized nature of family law education has other consequences as well, among them the absence of any consistent definition of what "family law" includes. ${ }^{11}$ In the 191 law schools accredited by the American Bar Association, ${ }^{12}$ there are likely more than 191 different approaches to the subject. ${ }^{13}$ The participants in the FLER Project agreed, however, that certain contents and methodologies dominate, but fail to capture the reality of contemporary family law. ${ }^{14}$

Most of the books used to teach family law emphasize litigated appellate cases, virtually to the exclusion of everything else. In a review of eight standard family law texts, ${ }^{15}$ Professor DiFonzo and his students discovered that $79 \%$ of the pages were devoted to case material or statutes, with the vast bulk of those pages being case law. ${ }^{16}$ Although family courts increasingly hear and rely on social science data, ${ }^{17}$ the mean family law text for classroom use contained 1,166 pages, only 18 (1.5\%) of which involved social science. ${ }^{18}$ Clearly many (probably most) family law teachers supplement their casebook assignments with statutory 
or social science materials. However, given the difficulties of mastering, synthesizing, and organizing the many topics a family law course might include, it is understandable that teachers will often default to the casebook. And even professors who provide supplementary readings may spend a majority of their time on appellate decisions. It is therefore important to ask whether the emphasis on litigated cases is a good - or even appropriate-way to prepare law students for their roles as family lawyers. There is reason to think it is not.

A heavy emphasis on litigated cases probably sends two messages, one appropriate and one questionable. On the positive side, it encourages students to develop the skill of close analysis of complex legal texts. All lawyers need this key skill, and most would agree that it improves with practice. However, the ability to read, synthesize, and apply legal rules is only one necessary skill among many. The negative effect of the texts' case law emphasis is that it subliminally conveys the message that what matters most in family law is what gets litigated. A family lawyer's central role, a student might conclude, is to design and present legal arguments to courts on a client's behalf. Litigation is, of course, part of what family lawyers do, but by every account of which we are aware, it is only a very small part. ${ }^{19}$ Thus, the net effect of this imbalance in teaching materials is an emphasis on a very narrow range of skills (largely legal analysis and the preparation of legal arguments), which will prove decisive in only a small fraction of family law cases.

The life of the family lawyer, as we heard it described again and again by FLER Project participants, involves much more than the analysis of cases and the preparation of legal arguments. Today's family lawyers, unlike their predecessors of the 1970s and 1980s, are very likely to find that the judge (for whom this traditional skill of analysis and argumentation has been honed) has been joined in the family court by a slew of other powerful actors: mediators, parent educators, custody evaluators, and parenting coordinators, some or all of whose services may be mandated by statute or court order and whose opinions or recommendations may hold great sway with the judge. ${ }^{20}$ Lawyers trained only in legal analysis and the preparation of legal arguments will find themselves at a loss trying to navigate terrain occupied by this coterie of professionals. In this new interdisciplinary system, the lawyer's role and the tools he/she needs to serve the client have been radically altered.

In addition, the vast majority of family law cases are ultimately settled, either by the parties themselves, through negotiation involving lawyers (whether traditional attorneys or the newer "collaborative lawyers" ${ }^{21}$ ) or by mediation. Many cases use a hybrid process, involving litigation, expert evaluations, and ultimately, a negotiated disposition, sometimes after a court ruling on a motion. Yet most commercial casebooks give students no sense that negotiated or mediated settlement is the norm. ${ }^{22}$ Nor do most of the teaching materials foster students' acquisition of skills as negotiators, mediators, or collaborators. ${ }^{23}$

Finally, family disputes are rarely calm and tidy. Most involve an array of emotions: anger, depression, sadness, and fear. Sadly, they often also involve violence or the threat or allegation of violence. ${ }^{24}$ Indeed, the family lawyer may be the first person to whom a history of serious family violence is disclosed. Family lawyers also frequently represent children, who, depending on their ages and maturity, may or may not be able to articulate their needs or form solid judgments and plans for the future. Family lawyers who ignore or are ill-equipped to respond to the emotions, the violence, or the child client's limitations act at their client's peril and their own. Fear of violence, for example, may render a client completely unable to move forward until safety planning is in place. Anger or depression may diminish a client's capacity to focus on his/her long-term needs or those of the children.

Lawyers need to think about - and law students need to talk about — how one helps a client in emotional turmoil to engage in effective planning despite the fact that it is difficult. Law 
professors are beginning to recognize these issues, ${ }^{25}$ but the development of teaching methods to address them has lagged.

Over a decade ago, the MacCrate Report spoke of the need for "building the [educational] continuum"26 - the connection between what happens in law schools and what happens in the practice of law. Writing more recently, the Best Practices Project of the Clinical Legal Education Association (CLEA) stated that "[a] law school's educational program should guarantee that each graduate will have the knowledge, skills, and values necessary to meet a new lawyer's legal and moral obligations to clients . .."27

The participants in the FLER Project argued - often quite passionately-that the conventional teaching of family law does not meet these goals. New content and new methods could benefit lawyers, courts, spouses, partners, parents, and children. The conversations then turned to what and how.

\section{TEACHING THE FOUR C'S}

Elementary education — at least in legend - is the province of the "three R's." We wondered, as we struggled to organize the recommendations and thoughts that the FLER Project working sessions produced, if it would be helpful to think of family law education in terms of "four C's": Content, Context, Conduct, and Competence. Each of these terms encompasses a set of rules, theories, skills, and orientations that is at least valuable, and arguably, indispensable for the family lawyer working in the interdisciplinary world of contemporary family courts.

\section{A. A BRIEF COMMENT ON CONTENT: A FAMILY-BASED CURRICULUM}

In their discussions, FLER Project participants only rarely focused on the Content portion of the family law curriculum. No participant quite said as much, but we believe they were making a crucial (and probably correct) assumption that family law courses already teach the basic architecture of family law.

The law professor participants also suggested that available commercial teaching materials are largely adequate to the Content task. They provide the seminal cases, generally with interesting and informative notes, and problems that allow students to test and challenge their understanding. ${ }^{28}$ But the FLER Project's participants strongly agreed that learning the cases is woefully insufficient for today's family lawyers. Might significant dividends result from a reorientation of the content away from the cases and toward a problem/hypothetica/ simulation-based approach?

If law school teaching were imagined as a camera, it would be taking photographs, not shooting video. Most litigated cases provide snapshots of a moment of crisis. Even if the lens speed is slowed down to encompass a longer sequence, the focus rarely shifts from the image framed for discussion. But family life is not still life; it is experienced over time, sometimes embroiled in a tortuous chain of events. A still shot may capture an event, but it rarely provides more than the narrowest of context. Family issues are best viewed not in the isolation of a triggering action or a sudden reaction, but rather as interconnected events woven into a life story.

The nature of family life suggests, and participants in the FLER Project workshops insisted, that family issues should be assessed, as much as feasible, over time and within their appropriate context (family unit or other relevant grouping). Family law curricula 
should be redesigned away from the dominant focus on case-based analysis and toward a family-based structure. This reordering will not be easy. It runs counter to the doctrinal focus cherished by generations of law professors, as well as to the case method, so ingrained that the profession's teaching texts are virtually always referred to as casebooks, with everything else about the law, such as statutory materials, scholarly articles, or empirical studies, relegated to supplement status. The social sciences have faced this same dilemma. As one scholar noted, "Since most data are a cross-sectional snapshot of families, families are assumed to be static. A more realistic (though much more difficult) approach is to recognize and analyze the fluidity, change, and transitions as individuals live in a variety of family patterns." ${ }^{, 29}$

One example may illustrate the deficiencies of topical coverage: it is not atypical for a basic family law course to discuss child custody one week and then parental relocation several weeks later, reflecting the placement of these topics in the casebook. It may be, of course, that a family's relocation dilemma is due to forces and events unrelated to the earlier family breakup. But it is also quite possible that the problems are interconnected. The relocation battle may stem from a resumption of an unsatisfactorily resolved custody dispute or a new struggle building on some other aspect of the family's history. But unless the teacher makes a concerted effort to connect the family history dots, the students may persist (as law students often do) in viewing each topic as a self-contained unit, more manageable for study and examination purposes.

Presenting students with the abundance of family law issues that may occur over time in a real (or simulated) family (or set of families) may furnish a contextually rich matrix, helping students to grasp the interplay of legal and social issues and their longitudinal effects. This approach would also allow and encourage law professors to increase their focus on family formation issues, such as marriage and adoption, rather than focusing so heavily on family dissolution. Professors Carl Schneider and Margaret F. Brinig have taken a stab at this task, constructing "economic and social histories of five financially various families." ${ }^{30}$ The goal of these histories is to provide "the basis for a detailed and concrete discussion of the casebook's materials on alimony, marital property, and child support." ${ }^{11}$ Similar summaries could be created to reflect a wide range of family issues, for example, following the history of a child in foster care. ${ }^{32}$ There are also longitudinal possibilities, that is, a set of problems could track one or more families as they confront a series of issues over time.

Although some Content-based discussions occurred at FLER Project sessions, for the most part participants devoted themselves to thinking about how the current Content could be supplemented to make the teaching of family law more relevant to contemporary practice. In the end, the participants agreed on the following:

* Family law needs to be placed in a larger context, including such matters as court structure, ADR, pro se litigants, domestic violence, financial issues, and more. Students need to be introduced to that context explicitly.

* Family law courses must make the time to address issues of attorney conduct. Family law teachers must make it clear that ethics, tactics, and roles are as important for students to study and ponder as the best interest of the child rule or the child support guidelines.

* Family lawyers need a wide range of skills — active listening skills; skills in counseling clients in emotional turmoil; negotiation skills; skills in financial, pension, and health insurance planning - only a few of which are mentioned in most commercial materials.

In the balance of this Report, we use the insights, reflections, and creativity of the FLER Project participants to suggest how law schools, the courts, professional associations, 
foundations, and others might work together to bring new directions and new emphases to family law teaching. While much of the burden of family law education reform will fall on the law teachers and the law schools, alliances with judges, mediators, child psychologists, financial planners, and others will both lighten the load and improve the product. And it will do more. As this Report explains, today's novice family lawyers are a precious resource that is largely being squandered. Through no fault of their own, they are all too often ill-prepared for the challenging task of helping spouses, parents, domestic partners, children, or families understand the legal problems they face and plan for their resolution in a productive, efficient, and respectful manner. The expertise law students need is available. The challenge for all of us who care is to deploy it.

\section{B. CONTEXT - WHAT IS FAMILY LAW'S LARGER SETTING?}

As we reviewed our notes and the charts, summaries, and comments that resulted from the FLER Project's several working sessions, we assembled a rough taxonomy of needed context. Though many ideas were put forward, we concluded that they arranged themselves into just a few groupings. These are (1) courts and family dispute resolution processes; (2) issues of class, race, gender, age, and power; (3) financial issues; and (4) issues of policy and law reform. Each of these topics was stressed in the FLER Project discussions, and each needs careful consideration in the reform of family law education.

\section{Courts and the Family Dispute Resolution Process}

The FLER Project was fortunate to count among its contributors a number of family court judges and many other professionals whose work is based in the family court. These participants brought the FLER Project the reality check of their on-the-ground experiences, and they stressed that family law teaching needs to better prepare students for what they will experience in the family court. But course material allowing family law teachers to provide this orientation is, as several of the law professors noted, what is most often missing from the commercial casebooks.

FLER Project participants argued that family courts have changed dramatically in the past 20 years. Changes in court process, they said, have effected change in family law's substance. The most dramatic example is the creation of unified family courts in roughly 13 states. ${ }^{33}$ While there are undoubtedly variations among these courts, the basic concept of a unified court is (1) that it has jurisdiction over all issues involving family status or children and (2) that it is part of the "therapeutic justice" movement, which "evaluates the legal system by applying mental health criteria." 34 In these courts, judges do not sit primarily as fact finders or decision makers. Instead, they oversee a multidisciplinary group of service providers who work with the adults and children whose issues are before the court. In this model, a single court groups such disparate issues as domestic violence and modifications of child support. The common thread is that these issues involve families. In some of these courts, all of the issues involving members of the same family will be supervised by a single judge. ${ }^{35}$

Only a minority of states have a unified family court. At the other end of the spectrum are states that have no specialized court for family issues at all. ${ }^{36}$ In these states, a claim that a parent is a substance abuser and a danger to his child is heard in the same court, and under the same rules, as one involving an overdue credit card bill or the placement of a fence. Professor Babb's research identified 34 states with specialized family courts, though 
in some instances only part of the state is served by this court ${ }^{37}$ (presumably, in the rest of the state family law cases are, again, heard in the general trial courts.) Clearly, courts also exist at points in between. Without adopting the unified court model, some family courts have created in-house court clinics staffed by social workers and other mental health professionals. ${ }^{38}$ In some locations, all child custody and visitation disputes must be referred for mediation. ${ }^{39}$

Wide disparities in matters as basic as the definition of the judge's role are clearly a challenge for commercial publishers and family law teachers alike. For law schools whose students largely intend to practice in the local jurisdiction, the approach is somewhat easier. Law professors can follow the urging of FLER Project participants and forge alliances with local family law judges and practitioners. The latter could be invited into the classroom to discuss court processes, and visits to the local family court could be arranged.

For schools whose students scatter to multiple jurisdictions, the task is harder, but no less crucial. These students should be introduced to a variety of models of family court processes. Some can be viewed directly through visits to the local courts, others can be studied through textual materials or videos, if the latter are available. Students need to understand the therapeutic jurisprudence model and the safeguards provided (or lacking) for affected litigants. They need excellent hypothetical cases in which the consequences of parceling out the various issues affecting a single family in a non-unified court system can be demonstrated.

The movement toward a social service model for courts has both its advocates and its critics. Students of family law would be well served if the many current variations in family court structure were introduced and subjected to rigorous analysis and criticism. ${ }^{40}$

\section{ADR and Family Law}

Another major theme of FLER Project discussions was that the methods of dispute resolution being applied to cases of family conflict are changing — or have changed—without a corresponding change in the focus of family law courses. Even in the many states that have not adopted the unified court model, it is extremely likely that alternatives to the actual trial of family disputes - most prominently mediation - play a far greater role now than they did 20 years ago. ${ }^{41}$ Beginning in the 1970s, at least three states (California, Minnesota, and Wisconsin) began to base mediation services in the court itself. ${ }^{42}$ At the same time, private mediation, most specifically for divorcing couples, was expanding rapidly. ${ }^{43}$ Today, "[a]n estimated 12 states mandate family mediation when there are disputes over custody or visitation, as do a number of local jurisdictions. Nearly all courts have discretion to order mediation in selected cases." ${ }^{44}$

Whether mandatory or voluntary, whether limited to issues of custody and visitation or extending to matters of support, health insurance, and the financing of educations, mediation is both widely available and widely imposed in family law cases. The prospective family lawyer who does not understand this fact operates at a significant disadvantage, which is likely to adversely affect the lawyer's clients. Family law students need to understand the prominent role of mediation and mediators in contemporary family courts. They should be familiar with the different models of mediation - facilitative, evaluative, and transformativeand with hybrid mediation processes and other hybrid approaches to dispute resolution. They should understand how mediators interact with lawyers and family courts, and they should be introduced to the uses and abuses of "mandatory mediation." ${ }^{45}$ The developing field of mediation advocacy should be introduced, ${ }^{46}$ along with models of collaborative law $^{47}$ and cooperative law. ${ }^{48}$ The use of court-appointed experts on issues from valuing 
assets to recommending custody should be carefully explored as well. Within each area, in addition to the important "how to" materials, law students should be exposed to key critiques, for example, gender-based critiques of mediation ${ }^{49}$ and the continuing dispute about mediation in cases involving domestic violence. ${ }^{50}$ Faculty may want to familiarize themselves with the ongoing "standards movement," which is affecting many of the professionals who work in or in conjunction with the family courts. Although mediators have had published professional standards of conduct since 1984, for many of the newer roles, such as parenting coordinator, standards are only now being devised. ${ }^{51}$

Finally, students should discuss the uses and abuses of litigation..$^{52}$ Litigation was designed to be, and is, a dispute resolution mechanism. It is a method of arriving at an answer to a question: Will the marital home be sold? Should alimony terminate after 3 years? Should visitation be supervised? In the majority of cases, litigation is a very costly dispute resolution mechanism, in terms of both dollars and time. It can produce a hardening of the parties' positions during the many months a case is pending. In addition, while it will ultimately provide a judicially imposed resolution of the issues submitted to the court, litigation may fail to encompass all of the problems a family faces. Finally, many of the proponents of mediation argue that mediation can teach disputants methods of problem solving and conflict resolution that they can apply to later disputes, should any arise. Litigation does not teach such mechanisms.

Litigation, however, has the advantage of providing an imposed resolution of at least the major issues in a family dispute when the parties are, for whatever reason, incapable of resolving the issues otherwise. If one party is mentally ill or irrational, for example, litigation may be a more effective means of resolution than forms of ADR. If past violence has rendered a victim incapable or unwilling to negotiate or mediate with the abuser, litigation offers her (or him) a method of dispute resolution that requires only minimal engagement with the abuser. Furthermore, if parties simply reach an impasse, litigation can end it through a legally imposed solution. Litigation will always be necessary, and in a number of cases, it will be wise. While family law courses need not teach litigation skills, family law students should be strongly encouraged to complete a course in civil litigation skills. Internships or clerkships in the family courts can also provide family law students and recent graduates with exposure to the litigation of family disputes.

While only a small minority of cases is litigated, a lawyer needs to identify the case that requires litigation and pursue that alternative when it is appropriate. Indeed, one of a family lawyer's key tasks is helping the client choose the dispute resolution process that is most likely to resolve her case effectively. Clearly, this requires as a starting point understanding what the client's options are and the pluses and minuses of available alternatives. While many family law casebooks discuss mediation, they do not alert students to its prominence, its complexity, or the lawyer's role if mediation is chosen or imposed. This is clearly an area where law professors need to learn more and share that learning with their students. ${ }^{53}$

\section{Family Law as an Interdisciplinary Practice}

The FLER Project was designed from the outset to give a strong voice to many professionals - custody evaluators, parent educators, mediators, and others - who work in the courts and/or with families involved in disputes, but who are not lawyers by training. These professionals play a powerful role in many of today's family courts. In some states, their presence reflects the adoption of the unified family court model or something similar: a reorientation of the family court that stresses service provision (mediation, counseling, etc.) 
rather than fact finding and court orders. In other states, the change is less radical, though in the same direction. The shift of family courts to this interdisciplinary model-along with the key role played by ADR providers ${ }^{54}$ - formed a constant backdrop to the discussions, analyses, and arguments of the FLER Project.

The new reality of family law practice makes it essential that law students have at least a rudimentary understanding not only of the roles non-lawyer professionals play, but of the theories and assumptions on which they rely. For example, psychological theories are routinely presented to courts by custody evaluators, ${ }^{55}$ and in at least some (and perhaps many) cases, they form the basis for the court's order. ${ }^{56}$ As things now stand, however, many (probably most) of the students who receive credit for a course in family law have never heard of family systems theory, parental alienation, borderline personality disorder, or other psychological constructs that have, at various times, strongly influenced judicial decisions and legislative enactments. Indeed, family law students may not have heard of custody evaluators, parent educators, parenting coordinators, or the other professionals with whom they are likely to interact in the course of their very first case as practitioners. Many of the casebooks already include cases on topics such as custody modification or parental relocation. These can be excellent vehicles for a focused discussion of the roles, contributions, and limitations of these experts and their testimony. Without their professors' help, however, students are unlikely to appreciate the significant role that these experts play in many cases. $^{57}$

How can a family law course get students up to speed on so many complex issues? Again, the open-door approach advocated by many FLER Project participants could provide a start. Law professors could reach out to local custody evaluators and vice versa. The evaluators could describe their work, the theories and studies on which they rely, and their view of their role. Perhaps professors could invite custody evaluators to speak in their classes. Reaching out to other court-affiliated professionals, professors might arrange for students (and themselves) to observe a parent education class, view a videotape of a class, or see a simulated interaction between a parenting coordinator and a family member. Students could ask questions and offer reactions to these processes, and they would enter practice markedly better informed about what their clients face.

Failure to appreciate the roles of the dispute resolution and mental health professionals who work with the family courts is a serious error. Family lawyers cannot adequately represent their clients without knowing who these actors are and the assumptions from which they proceed.

\section{The Pro Se Explosion}

A study published in 1999 noted that twenty percent of the divorcing parents questioned "believed that the [divorce] process would operate much smoother if attorneys were excluded altogether." 58 Taking matters into their own hands, many litigants have made that wish a reality. Numerous studies have confirmed the view of the American Academy of Matrimonial Lawyers that "[c]oncern for the problems and expense of the divorce system has caused an increasing number of parties to attempt to navigate the process without the assistance of a lawyer." 59 The phenomenon of unrepresented or self-represented (pro se) litigants has both changed and challenged family court judges, court personnel, lawyers, and the litigants themselves. FLER Project participants attributed the rise in lawyerless litigation to two causes: the high cost of legal services (with insufficient access to low-cost or free legal representation) and a rejection of the services lawyers offer in family disputes. ${ }^{60}$ 
Family law teachers need to talk with their students about pro se litigants and their substantial impact on the family courts. Materials describing the phenomenon should be assigned, and the ethical issues it raises for practitioners should be spelled out, perhaps through the use of a set of challenging problems. How does an attorney proceed appropriately in a case when the other party is representing him/herself? Ethics rules do address the issue, but they barely scratch the surface. They admonish the attorney representing a husband, for example, not to give advice to his wife if she is representing herself. It is certainly important that the lawyer know this, but what is the lawyer to do, for example, if the wife makes an error that helps the lawyer's client, but that is clearly a mistake of consequence? ${ }^{61}$

As the twenty-first century progresses, legal services themselves are in flux. Developments such as "unbundling" (also called "limited task representation"), ${ }^{62}$ reduced fee panels (where attorneys agree to represent financially eligible clients at a reduced rate) ${ }^{63}$ increasing pro bono representation, ${ }^{64}$ and the emergence of collaborative lawyering are forces moving family law at the present time.$^{65}$ FLER Project participants maintained that law schools need to prepare students for the challenges and opportunities in family law resulting from the dramatic rise in the numbers of pro se litigants. ${ }^{66}$

\section{Class, Race, Gender, Age, Power}

Considering the enormous impact that factors like class, race, and gender have on people's lives, it is not surprising that these issues emerged in various forms as the FLER Project participants labored to design a law curriculum for the twenty-first century. They - in particular the law professors - told us that the curriculum needs to recognize that wealthy clients and poor clients, female clients and male clients, immigrants and citizens, may all present different issues and be subjected to different treatment by the legal system. These issues of class, race, gender, and power, they said, should be directly addressed by the family law curriculum.

a. Cultural diversity. Several of the law professors in our discussion groups complained that the commercial family law texts treat families as though they were fungible. The parties' race, immigration status, ages, and income are rarely mentioned in the cases students study. But these factors are likely to have a dramatic effect on individuals' access to legal services and to the courts; their ability to purchase private mediation services, therapy, or other supports; their ability to communicate in English; their literacy; their treatment by the courts; and more. ${ }^{67}$ Of course, in some of the classic cases, matters such as marital status are the very focus of the court's analysis. ${ }^{68}$ The law professors noted that very little in the published materials focuses on single-parent families, blended families, stepparents, gay parents, or poor parents. If these groups are mentioned at all, it tends to be to note their exceptionality.

Another thread in the conversations suggested that perhaps the division in some states and courses between Family Law and Juvenile (Children's) Law actually reflects a cultural and wealth-based division that is not identified as such. That is, people appearing in the courts that handle delinquency, dependency, and child abuse and neglect are largely poor and disproportionately members of racial minorities. ${ }^{69}$ In those states in which a different court is primarily concerned with divorce, the parties in that court are much more likely to be White and middle class ${ }^{70}$ and to have brought their dispute to the court, rather than having had the legal system drag them there. ${ }^{71}$ Yet, it is easy to teach a family law course without 
ever discussing the impact of wealth, race, immigration status, and so forth on families and their relation to the legal system and without pressing students to focus on the push/pull of the system (i.e., did the client come to the court or the court to the client?).

b. International and comparative perspectives. Related to the lack of focus on cultural and economic diversity in the United States is the long-standing failure - now, hopefully, beginning to be remedied - to discuss families and family law in a comparative/international context. A comparative perspective would introduce students to the many ways in which U.S. family policy differs markedly from that of other developed countries. U.S. policies stress gender equality and individual freedom, an ethos that suggests that individuals and families - not government - are responsible for their own well-being. This cultural character has obvious benefits, fostering family self-determination and individual autonomy. But there are cultural side effects as well. American families are, for example, alone in the developed world in having to provide for their own health care unless they qualify for Medicaid ${ }^{72}$ or SCHIP, ${ }^{73}$ the federal programs for poor individuals or children. Currently, some $11.2 \%$ of American children fall through the health care cracks - a total of 8.3 million uninsured children. ${ }^{74}$ Students may also be unaware that children are the group most likely to live in poverty in the United States. ${ }^{75}$

In addition to this comparative view, an international perspective on family law would include, at a minimum, study of the United Nations Convention on the Rights of the Child. ${ }^{76}$ This convention has been ratified by 191 of the 193 United Nations member states. Only Somalia and the United States have declined to ratify the Convention. Another international convention of great significance to family law teachers is the Hague Convention on International Child Abduction, which the United States has ratified and implemented. ${ }^{77}$

A new focus on international perspectives is sweeping the law school curriculum, including — if slowly — the family law curriculum. ${ }^{78}$ In this age of globalization and growing concern for human rights issues, the particular strengths and vulnerabilities of American families may be best viewed through an international and comparative lens.

c. Intimate partner violence. Although domestic violence ${ }^{79}$ is arguably part of family law's basic canon, a number of FLER Project participants stressed that it is easily pushed aside, as time pressures favor other, seemingly more central, topics. We believe that family violence merits special attention for several reasons. First, it is extremely widespread and its etiology is not widely understood. ${ }^{80}$ Second, the history of societal responses to domestic violence provides an excellent window into the ways in which gender may shape legal policy.

More importantly, however, intimate partner violence (IPV) should be a key concern for family lawyers because its effect on all other family law issues is enormous. IPV may affect a woman's ability to support herself and her children. ${ }^{81}$ Victims of domestic violence often require medical care, although they may conceal the cause of their injuries. ${ }^{82}$ IPV may also have considerable impact on child maltreatment and parental fitness. ${ }^{83}$ The interplay between a family court matter and an actual or potential criminal prosecution for domestic violence may be quite problematic, and difficult issues of legal ethics also come to the fore in cases involving IPV. ${ }^{84}$

Teaching law students to recognize IPV, and to deal in a professional capacity with both victims and perpetrators, requires both legal and psychological sophistication. Approaching the topic by co-teaching it with a mental health professional could pay enormous dividends. As Professor Joan Meier has observed, "[ $\mathrm{t}]$ he need for an interdisciplinary approach is 
especially compelling in the field of domestic violence, an issue which cuts across psychology, sociology, public policy, criminology, medicine, public health, and law." 85

A Report of the ABA's Commission on Domestic Violence suggested that "many lawyers are inadequately representing victims of domestic violence." ${ }^{\prime 86}$ Both family lawyers and health care providers are frequently consulted by victims of domestic violence. The medical profession has begun to implement routine screening for domestic violence, ${ }^{87}$ and models exist that would allow the legal profession to follow suit. ${ }^{88}$ The Commission on Domestic Violence attributed lawyers' failings in this area to inadequate training and maintained that "[1]aw schools can help remedy this deficiency in legal education by incorporating domestic violence information into core curricula courses, upper level courses, clinical programs and other law school activities." 89 However, outside of the clinical context and courses on feminist jurisprudence, few courses other than family law cover domestic violence. Even within the core family law course, most casebooks devote relatively few pages to the subject. ${ }^{90}$ "Too often students graduate from law school without an understanding of how domestic violence impacts the lives and legal claims of their clients." ${ }^{.1}$ The ABA Commission on Domestic Violence concluded that, if law schools provided more education about domestic violence, "legal professionals will be better equipped to (1) competently handle domestic violence cases in their offices and in the courtroom, (2) promote the safety of their clients, and (3) work towards improving the legal system's and the community's response to family violence." ${ }^{92}$

For all these reasons, a family law curriculum should pay significant attention to IPV.

d. Child maltreatment. As with IPV, compelling reasons warrant special focus on child maltreatment ${ }^{93}$ within the family law curriculum. Child maltreatment is extremely widespread. During 2003, 1,500 children died from abuse, and approximately 906,000 children were determined by state and local child protective services to be victims of child abuse or neglect. ${ }^{94}$ Like IPV, child maltreatment has a complex etiology. ${ }^{95}$

Society's evolving response to the abuse and neglect of children provides a rich study of changing social norms and legal policies, from the common law's abandonment of children to the patriarchal authority of their fathers, ${ }^{96}$ to the emergence of child abuse as a distinct academic subject in the $1960 \mathrm{~s},{ }^{97}$ to the further elaboration of the Battered Child Syndrome as including a recognizable cluster of symptoms typical of the chronically abused child, incorporating both physical and psychological maltreatment. ${ }^{98}$

Finally, like IPV, child maltreatment may serve as a marker for other substantial problems, both within and outside of family law..$^{99}$ Although the two types of family violence, IPV and child maltreatment, deserve separate curricular treatment, domestic violence and child abuse often occur in the same households. ${ }^{100}$ In fact, a majority of studies indicate that in $30 \%$ to $60 \%$ of families where either child maltreatment or woman battering is identified, the other form of abuse will be present as well. ${ }^{101}$

As the ABA Standards of Practice for Lawyers Representing a Child in Abuse and Neglect Cases reflect, the responsibilities of attorneys in this field are simultaneously detailed and broad..$^{102}$ Moreover, while an interdisciplinary approach to family law can be valuable in a number of settings, training beyond the purely legal is indispensable for the legal practitioner in the field of child protection:

Professionals who interact regularly within the child protection system include lawyers, social workers, psychologists, police officers, physicians, and teachers. These professionals often serve on interdisciplinary case review teams or cooperate in preparing a case for trial. 
Mutual understanding between [sic] these professionals assists in eliminating the confusion, delays, and poor decisionmaking caused by professionals unprepared to interact with one another. Participants in the child protection system should understand the limits of their own disciplines as well as understand and respect the skills and knowledge unique to the other disciplines represented in that system. Interdisciplinary training can accomplish these goals and thereby enhance the effectiveness of professionals involved in child protection. ${ }^{103}$

Because child welfare law is regularly undervalued by law schools, it is rare for a law school graduate to arrive in court prepared for the challenge of representing the special legal interests of a child. ${ }^{104}$ That law schools fail to teach practical information to the child abuse professionals of tomorrow means these professionals must learn on the job with the lives of children hanging in the balance. ${ }^{105}$ The study of child maltreatment is a vital component of family law and deserves enhanced focus in the family law curriculum.

\section{Financial Issues}

Law professors raised the importance of financial and related matters in client counseling. ${ }^{106}$ The discussion was not lengthy, but an area of great concern was that some professors lack the financial expertise that our students will be expected to take with them into practice. Family law clients present their lawyers with a broad range of issues: emotional, practical, and financial. Some clients have substantial wealth and need advice about the tax implications of divorce, family trusts, dividing a business, and similar matters. Clients at the other end of the spectrum may be receiving or may need to apply for public benefits. In the middle are many clients who think of themselves as having few resources, but whose modest homes and pension credits may, in fact, pose complicated problems of tax and valuation that require careful handling.

Even the most garden-variety divorces may require a lawyer to deal with ERISA, ${ }^{107}$ capital gains tax, ${ }^{108} \mathrm{TANF}^{109} \mathrm{COBRA}^{110}$ and other complex tax and benefit issues. Many commercial family law materials are of little help, particularly on the issues likely to affect poorer clients. This may be an area where including family law on the bar exam has an unintended negative consequence. Because what the bar exam tests is state-based doctrine, not tax and benefits programs, this would reinforce law professors' tendency to stay away from this crucial material, despite its enormous impact on client well-being.

\section{Policy and Law Reform}

Another relatively brief but intriguing conversation among the law professors focused on teaching students about issues of policy. The professors noted that law students are expected to learn so many rules and doctrines that it is hardly surprising that many of them view their central task as grasping the law as it currently stands (that is, after all, what the bar exam tests). If asked, students would probably agree that law is constantly changing, but current teaching (and examination) methods may discourage students from thinking deeply and critically about the evolving nature of law. This narrow orientation may have significant costs.

A number of the law professors spoke ruefully of the difficulty they encounter in trying to engage students in discussions of legal policy. Because students have defined their task as grasping and applying current law, they resist considering, foreseeing, or working toward different legal rules and practices in the future. 
The law professors' view was that law and social change are often closely related, with cause and effect flowing in both directions. As a consequence, lawyers would do well to envision themselves as both agents and objects of change. The law professors suggested two ways to engage students in the study of law and social change:

(1) historical context: class sessions and readings could demonstrate how an event or series of events outside of law caused the law to change ${ }^{111}$

(2) current context: students could be helped to consider forces presently at work and the changes they may be affecting in family law. ${ }^{112}$

As the law professors spoke, they identified religion, the economy, demographic shifts (the baby boom, immigration), and the evolution of social science theories (particularly those relating to children) as having major formative effects on family law.

\section{Conclusion: The Goal of Context}

The participants in the FLER Project endorsed the view that a legal education should emphasize the following points in order to set family law in its broadest and most useful context:

* family law is part of an ongoing process of social change

* family courts are in flux, and there are significant differences among the states and even within states

* the field is daily affected by many disciplines other than law

* there are multiple processes for resolving family disputes, and the lawyer has an important client counseling role in selecting and guiding the client through the web of dispute resolution processes

* the American legal system is only one of many possible approaches to family law issues; international and cross-cultural perspectives on the family and family law can be extremely valuable

* an historical and cultural frame of reference is crucial for all legal analysis

A student with this sort of preparation would be far readier to contend with the rapidly changing, multidisciplinary reality of contemporary family law.

\section{CONDUCT-ETHICS, CIVILITY, AND OTHER DUTIES}

FLER Project discussions frequently turned to the topics of ethics and civility and the need to repair the public's poor image of family lawyers. These topics had a tendency to blend into one another. Thus, although we try to discuss the categories separately, there is clearly overlap among them.

\section{Fostering Professionalism}

a. Family lawyers and ethics. Participants in the FLER Project workshops identified an emphasis on ethics as being both critically important and often missing in family law curricula. Interestingly, the nonlawyers in the group articulated a very broad conception of the ethical issues family law raises, a conception that encompasses far more than compliance with the rules of professional responsibility, and stresses the welfare of the family unit ahead of that of any 
individual. Some participants noted that other law school courses, including the specific course on legal ethics, stress the ethical requirement of competent advocacy. But no course, with the possible exception of some extraordinary ADR offerings, helps law students to grapple with this question: how do lawyers meet their ethical obligations to their clients in the nonadversary milieu in which family law conflicts are often resolved? How does one advocate vigorously for one's client's needs without creating or spiking antagonism? Stated another way, how can a lawyer be sure that he or she is providing excellent representation in a system that constantly presses for compromise and concession? Many FLER Project participants urged a much sharper focus (necessarily requiring more time) on legal ethics in courses on family law.

Noting that existing ethics codes provided inadequate guidance to the matrimonial lawyer, the American Academy of Matrimonial Lawyers issued its Bounds of Advocacy in 2000. The goal was to elevate the standards and advance the cause of matrimonial law, to the end that the welfare of the family and society be preserved. ${ }^{113}$ These guidelines mark a clear break with the traditional view that a matrimonial lawyer's only job is to win. Instead, the guidelines encourage other models of lawyering and goals of conflict resolution in appropriate cases. ${ }^{114}$

Many state and local bar associations have supplemented the ABA Model Rules of Professional Conduct ${ }^{115}$ with codes of professionalism focused on family law practice. ${ }^{116}$ For example, the Los Angeles County Bar Association Professionalism Guidelines for Family Law Practitioners prohibit churning, ${ }^{117}$ economic harassment or coercion of the adverse party, ${ }^{118}$ and vindictive litigation. ${ }^{119}$ The MacCrate Report stressed recognizing and resolving ethical dilemmas, naming this one of the ten key lawyering skills. ${ }^{120}$ The four basic professional values noted in the MacCrate Report are also linked to ethics concerns. The values include the provision of competent representation; striving to promote justice, fairness, and morality; working to improve the profession; and professional self-development. ${ }^{121}$ These skills and values need to be discussed overtly and stressed repeatedly if law teachers hope to enhance the performance and reputation of family lawyers. Attorneys who choose family law practice face an especially wide array of ethical and emotional dilemmas. They are called on to exercise a broad range of skills, and they must interact ethically and effectively with professionals from many disciplines. ${ }^{122}$

b. Family lawyers and civility. In addition to stressing the ethical pitfalls and obligations that are so dominant in a family law practice, law professors might also focus sharply on the fact that dignity and respect are essential to all lawyering. Family law professors should directly engage their students in discussions of the field's reputation and the sad reality that family law practitioners have often been perceived as uncivil.

Many state and local bar associations, as well as the American Academy of Matrimonial Lawyers, have codes exhorting respect and courtesy. ${ }^{123}$ The Los Angeles Professionalism Guidelines highlight the potential for incivility in directing family lawyers not to withhold or delay experts' reports in order to gain a strategic advantage, not to harass opposing counsel by misusing or overusing facsimile machines, and to return telephone calls to opposing counsel within a reasonable period of time. ${ }^{124}$ While aggressive or belligerent conduct may well have its roots in the broader culture, this does not exonerate the law schools. Law professors need to take on the challenge of engaging students in direct discussions of these issues. ${ }^{125}$

\section{Educating the Public About the Family Law System}

Intimately connected with ethical duties is the need for the family bar to improve the public's image of family law practice. ${ }^{126}$ Many FLER Project discussants observed that the 
media portrays family law as a battlefield in which all soldiers litigate. The consumer of legal services (i.e., the public) is strongly influenced by this cultural portrayal of the Rambo lawyer. ${ }^{127}$ Law students absorb this mindset and fail to realize that family lawyers increasingly use (and many have always used) problem-solving and collaborative techniques. Law teachers need to stress this alternate reality. They can assign materials that demonstrate that lawyers who help clients to settle cases ethically and collaboratively are both successful and respected in the profession. Not only have these lawyers always been in the majority, they achieve better substantive results. ${ }^{128}$

\section{Role-Modeling Behaviors}

Law teachers should introduce students to the many professionals whose work may involve them with the family court. Just as legal professionals may be invited to serve as guest lecturers, dynamic mental health and dispute resolution practitioners may educate and motivate students. FLER Project participants remarked that law professors seldom invite judges or practicing attorneys to address their classes. Family law students would benefit by hearing from a wider array of professionals, such as mediators, parent educators, custody evaluators, forensic accountants, and mental health professionals. Some of these professionals could serve as adjunct teachers, but even in a guest lecturer role, their presence illustrates the value of cross-disciplinary perspectives. A significant benefit of this exercise is that students see the law professor relating to professionals in other disciplines as partners and co-teachers, not merely as resources.

\section{COMPETENCE—ENHANCING THE QUALITY OF FAMILY LAW PRACTICE}

If the law professors weighed in heavily on context, it was the mental health professionals and mediators who argued, often quite passionately, that new lawyers' skill sets are usually woefully deficient. In many FLER Project discussions, a major goal was to identify and flesh out the essential competencies of the novice lawyer. As we tried to organize the wealth of ideas offered on this topic, we struggled to identify and label the multiple roles family lawyers are asked to play. We concluded that a lawyer is a communicator, an educator, a counselor, and a manager, who may be called on to work independently or as a member of a team. Indeed, family lawyers may enter and exit several teams as a legal problem proceeds to its resolution. ${ }^{129}$

\section{Lawyer as Communicator}

It would be hard to think of any professional who would not benefit from strong communication skills, but many participants argued that a lawyer needs a special subset of communication skills, which are rarely mentioned in the law school curriculum.

a. Active listening skills. Respondents to the FLER Project survey identified listening skills as the most significant skill set for an effective family lawyer to acquire. ${ }^{130}$ Far from giving lawyers high marks on this skill, however, several participants described lawyers as needing to dominate and structure conversations, even when the conversation consisted of a client (or other person) trying to give the lawyer information which the speaker knew and the lawyer did not. Others asserted that lawyers listen only for facts, missing the emotional content of what is being conveyed. Still others said that lawyers listen only for legally relevant facts, thus missing not only affect, but factual material as well. 
In some professions, such as psychology and social work, students are given explicit instruction in the art of listening. ${ }^{131}$ Family law professors might collaborate with colleagues who already teach listening skills to develop appropriate exercises. FLER Project participants stressed that lawyers and their clients would benefit enormously if instruction of this type were routinely provided to law students. ${ }^{132}$

b. Handling emotional content. Family lawyers are frequently asked to listen to stories that are difficult for the client to tell. These may involve intimate details that are not usually shared (particularly with strangers) or embarrassing or frightening events. FLER Project participants argued that a lawyer must listen to such revelations with both empathy and respect. Doing so allows the client to vent appropriately, and then, with the lawyer's guidance, focus more clearly on the future.

Among the many criticisms leveled at fault divorce as the no-fault movement was building was that it at least encouraged, and perhaps forced, divorcing couples to dwell on the damage they had inflicted on each other as their marriage deteriorated. This conduct, after all, would prove the fault ground which was essential to obtaining a divorce. ${ }^{133}$ Today, all states offer divorcing couples some form of no-fault divorce. ${ }^{134}$ As a result, the legal process of divorce no longer requires allegations and proof of a spouse's bad conduct. Contemporary legal reality, however, is a bit more mixed. Some states retain fault grounds for divorce, having added a no-fault ground as an alternative. ${ }^{135}$ Marital fault also remains relevant to alimony awards in some states, even if the ground for the divorce action is a no-fault ground. ${ }^{136}$

The FLER Project's participants suggested that the rearward focus and blaming, which were essential parts of fault divorce, have not disappeared. People whose marriages or serious nonmarital relationships have ruptured are likely to feel angry, frightened, and humiliated. ${ }^{137}$ The actively listening lawyer must hear not only the facts of the client's case, but the emotions that embellish it as well. But, the FLER Project participants argued, while the lawyer must remain respectful and empathic, he or she also needs to turn the client from the rear-view mirror back to the road ahead. The lawyer's job may be to listen to the client's anger and pain, and to acknowledge their validity, but the conversation cannot stop there. The client needs the lawyer's help in resolving the family crisis that has engulfed him or her. That requires a focus on the future, both short term (as in arrangements for temporary custody and access to children and temporary financial arrangements) and long term. FLER Project participants told stories of lawyers who, rather than encouraging this future perspective, urged their clients to focus sharply on their soon-to-be-ex-spouse's faults and behavior. The participants saw this as a serious disservice.

The issue is complicated, and the FLER Project's participants did not provide a roadmap for law teachers to follow in inculcating the orientation they seemed to be urging. This also seems to be an area where clients who have been victims of domestic violence might require very different treatment than other clients. For example, while a client whose husband engaged in an extramarital affair might well be advised to accept the past, another client whose husband's assault landed her in the hospital might need to focus sharply on the past as the basis for essential safety planning.

We concluded that these conversations about helping clients handle the emotional content of family law disputes were important, but probably need further refinement in order to help law professors do the right thing in this area.

c. Setting boundaries with clients. Mental health professionals use the word "boundaries" frequently, both in describing their patients and with reference to their own work. In the 
course of the FLER Project discussions, these participants urged that young lawyers be taught (1) what boundaries are, (2) why they are important, and (3) how to set them. Stated a bit simplistically, the root idea of boundaries is that no person has the right to invade the psychic and emotional space of another. To use a simple example, a patient in therapy should not be allowed to phone her therapist's home. The patient will probably be instructed to leave messages on the therapist's business phone, which the therapist will then retrieve and respond to. A therapist who fails to enforce such a rule has failed to set a boundary, and both the patient and the therapist may suffer substantially as a result.

The FLER Project's participants encouraged law professors to talk to students about boundary setting. They argued that this is an essential component of any relationship that is likely to involve difficult emotional content and an imbalance of power. In negotiating their boundaries, lawyer and client should set clear rules to protect both of them as the family dispute runs its course toward resolution.

d. Communicating with a child client. The lawyer whose client is a child needs the skills to engage in developmentally appropriate communication. Like any other client, the child client must be kept abreast of the progress of his or her legal case. But the updating process will need to be adjusted in light of the child's developmental stage. The attorney for the child must also be prepared to help the child participate in the legal proceedings in ways that are developmentally and psychologically appropriate.

\section{Lawyer as Educator}

The family lawyer's job is to help the client resolve a legal problem. The resolution of that problem may require negotiation, the preparation of documents, litigation, or other tasks, but a first objective must be to help the client define the nature and extent of the problem and the legal and practical framework in which it will play out.

Many of the psychologists and social workers in the FLER Project working sessions expressed the view that lawyers spend too little time explaining the family law process to their clients. Divorcing couples seem bewildered by mandatory mediation, parent education, financial matters, and a host of other issues. Of course, as the sections above demonstrate, lawyers, particularly neophytes, may know very little about these topics themselves, which would clearly explain their failure to discuss them with their clients. The FLER Project participants urged that lawyers should understand that some clients will need appropriate referrals, so that they can be helped not only with the legal process, but also with its often turbulent emotional component.

How do we teach law students to teach their clients? Do conventional family law materials even suggest that this is an important part of the attorney's role? Because mental health professionals and mediators were major contributors to FLER Project discussions, it was the mental health and process issues, such as the effect of parental conflict on children, and the mediation/litigation comparison, that were stressed. ${ }^{138}$ But it is probably true that family lawyers should be far more proactive in educating their clients on a wide range of topics.

Many FLER Project participants commented that deficiencies in communication skills can greatly exacerbate the tensions surrounding a divorce or other family dispute. If a mediator is involved in the case, he or she may be able to help family members by teaching them more effective communication and problem-solving skills. Should lawyers be trained to help in this regard as well? 
A family law course could (1) present and stress the lawyer's educative role; (2) using selected topics as models, allow students to develop (and be graded on) a presentation of an issue to a mock client; and (3) use class time for student demonstrations of and feedback on the skill of client education.

\section{Lawyer as Manager}

a. Managing on the client's behalf. In accepting a client's case, a lawyer agrees not only to counsel the client to the best of his or her ability, but to manage the client's case, that is, to see to it that the problem the client is presenting moves along toward a (hopefully) positive resolution. The participants in the FLER Project suggested that law students should be encouraged (as they typically are not at present) to think of themselves as case managers.

1. Communications among professionals. The standard civil procedure course would suggest that managing a case means filing the appropriate pleadings and undertaking discovery. Most family law cases do involve pleadings and many involve formal discovery, but the management of a family law case is, the FLER Project participants told us, a much more complex undertaking. Many participants argued that, in many if not most family disputes, a lawyer should become a member of a team, which might include therapists, mediators, and others. ${ }^{139}$ While this assertion could certainly be debated, it seems incontrovertible (1) that many family disputes involve multiple professionals, sometimes through the client's choice, and sometimes by court order, rule, or statute ${ }^{140}$ and (2) that the parties to the dispute will be well served if there is good communication among the professionals. Knowing who is or may be involved in a client's case and coordinating with other important actors is a role every lawyer can and should perform. No FLER Project participant, however, could cite an instance of such a role being discussed in a law school setting. ${ }^{141}$

This management role and the educative role described above clearly overlap. In some cases, the lawyer may want to suggest to the client that involving other professionals, such as a therapist or a mediator, might be useful. (This presumes, of course, that the lawyer is familiar with the range and availability of services which the client might realistically access.) Indeed, this confluence of management and educative functions also raises communication issues. How can a lawyer broach such subjects? (A client may, for example, take umbrage at the suggestion that she or he needs to see a therapist.) And how will the lawyer determine that such advice is warranted? ${ }^{142}$

This issue of building and/or managing teams, like the issue of handling emotional content, was outlined by the FLER Project discussants, but not filled in. As the FLER Project teaching modules are developed, more time and thought must be devoted to structuring advice to law professors which will allow them to prepare students for this particular management role.

2. Time management. In addition to coordinating the efforts of the multiple professionals who may be involved in the client's case, the lawyer is the person primarily responsible for managing the case's progress. This means seeing that the case moves forward in as expeditious a manner as is consistent with its facts and the client's needs. That may sound like a circumlocution. In fact, however, many FLER Project participants argued that progress in the resolution of family cases must be sensitive to the emotional states of the parties. For example, one husband, wife, parent, or partner may be ready to engage in active efforts at problem solving, decision making, document preparation, and negotiation, while the other is not. If a client is ready to move forward, a key task for the lawyer is to put in place the mechanismswhether court filings, negotiation or mediation sessions, draft documents, or court 
appearances - that move the client's case along. If the client is not ready to proceed, the challenge for the lawyer is to try to identify the intervention or process that might help the client to feel ready to move forward. Perhaps safety planning is needed for an abused client, or a financial consultation for one who is paralyzed by financial worries. These challenging aspects of case management are not generally discussed in law school courses, but with the right hypotheticals, these conversations could easily be stimulated and steered by motivated faculty.

b. Managing the law office. Many family lawyers practice in small firms that do not generate the revenue that would make hiring a professional office manager feasible. As a result, the family lawyer is often left to manage not only his or her client's cases, but a business (the law practice) as well. The FLER Project participants noted that some law schools offer courses in law office management. ${ }^{143}$ These, they argued, should be strongly endorsed by family law professors, who should urge their students to enroll.

c. Managing one's self. Many of the topics addressed during the FLER Project's several sessions were predictable, but one that came up repeatedly was a bit surprising: young lawyers, particularly those who practice family law, need help taking care of themselves. This insight relates in part to the boundaries discussion above, ${ }^{144}$ but it goes further. Like any professional who is constantly entering high-stress situations, the family lawyer needs to learn coping techniques. He or she would also benefit greatly by identifying regenerative activities. ${ }^{145}$ Law teachers could borrow techniques and ideas from other stressful occupations and make them available to law students. ${ }^{146}$

\section{E. RECRUITING AND TRAINING TOMORROW'S FAMILY BAR}

\section{Recruiting Future Family Law Practitioners}

Some FLER Project participants called for law schools to work harder to attract and admit a more diverse group of individuals intending to focus on family law. Three rather distinct problems facing such an endeavor were highlighted. First, there is a marked gender disparity among family lawyers. After several decades of effort, law schools have achieved gender parity among law students. ${ }^{147}$ More women than men practice family law, however. ${ }^{148}$ The FLER Project participants believed that a gender imbalance among family law practitioners is unhealthy for both lawyers and clients, as was obvious in the days when the legal profession was a male bastion.

FLER Project participants also called for law schools to court more interdisciplinaryminded lawyers from undergraduate psychology and social work departments. This point reinforces a core conviction of the FLER Project: that contemporary family law is multidisciplinary and that those with a background in social science might be particularly well prepared for work in the field. ${ }^{149}$

The third issue addressed was the impact of the LSAT on law school admissions. The LSAT focuses on analytic abilities, ${ }^{150}$ not on lawyering skills more generally. Analytical skills are, of course, essential for attorneys. But these are the skills that conventional family law casebooks and courses stress, while slighting equally vital interpersonal and problem-solving skills. Some FLER Project participants believed that guidelines for law school admissions should consider a broader array of competencies than the LSAT measures. 
Finally, family law, like other fields, needs to recruit bright, driven, and devoted law students. This goal is particularly pressing in the traditionally low-paying public interest field of pediatric law. ${ }^{151}$ Some law schools have developed innovative programs with the hope of attracting excellent students to the family law field. The Bergstrom Summer Child Welfare Law Program at the University of Michigan Law School, for example, trains roughly sixteen fellows from various schools each summer. The Program includes a 3-day intensive interdisciplinary child welfare legal training, followed by placement of the fellows for 10 weeks in selected child welfare law offices or law clinics. ${ }^{152}$ Hofstra University School of Law offers Child and Family Advocacy Fellowships to attract students interested in learning and working in an interdisciplinary environment. Students are trained to provide effective representation for children, while they participate in ongoing education and research and improve services for children in need. ${ }^{153}$ Loyola University Chicago's Child Law Center offers innovative programs for students interested in pediatric law, including a 3-year fellowship for law students who are interested in developing the substantive knowledge, advocacy skills, and professional ethics needed to provide effective legal representation for children and families. ${ }^{154}$

\section{Implementing Certification and Focus Programs}

In 1991, Dean Robert A. Stein of the Minnesota Law School predicted that the law school curriculum of the future would offer far more specialized courses and seminars and that some schools would offer specialization tracks. ${ }^{155}$ The following year, the MacCrate Report on the legal academy's strained relationship with the legal profession explained the growing need for specialization:

[C]hanging law and new complexities have put an increasing premium on specialization to maintain competence and to keep abreast of subject matter. The process of professional differentiation has accelerated in clients served and kinds of legal work performed. Although solo and small-firm practice continues predominately to serve individual clients, the lawyers in these practice settings, like in other practice settings, are increasingly becoming "specialists." When asked, the great majority of lawyers now describe themselves as specializing by legal doctrine, lawyering skill, or type of client. ${ }^{156}$

Since the early 1990 s, the push toward specialization in the practice of law has grown stronger. The ABA Model Standards for Specialty Areas recognize twenty-four practice areas, and a number of states have formal certification programs for designated specialties. ${ }^{157}$ FLER Project participants urged law schools to develop options that would allow law students wishing to specialize in family law to enhance their qualifications. Law schools should provide these students with the opportunity to undertake focused cross-disciplinary research and/or advanced clinical placements. A good deal of FLER Project discussion focused on the possibility of awarding students certificates of specialization in family law, either along with their J.D., or as part of an LL.M. program. These concentrations would be both experiential and interdisciplinary. ${ }^{158}$

The University of Buffalo Law School has a Program for Excellence in Family Law, ${ }^{159}$ incorporating its Family Law Concentration and Family Violence Clinic. The Program aims to integrate teaching, research, policy, and practice to provide students with the skills and experience needed to practice family law and enhance the delivery of family law services to the community. ${ }^{160}$ In some locations, informal alignments across disciplines have been used to enhance students' exposure to family law practice. Northeastern University School 
of Law has partnered informally with the Child and Family Forensic Center of the University of Massachusetts Memorial Health Care Institute to have psychologists teach law students and law professors teach postdoctoral psychologists and psychiatrists interested in courtbased work with families and children. Northeastern also works with the Family Assistance Project - a legal/medical outreach program based in the pediatric unit of the Boston Medical Center. The Massachusetts General Hospital is the locus for the Children and the Law Project, whose directors and members have also contributed to Northeastern's programs. ${ }^{161}$

FLER Project participants strongly endorsed the establishment of specializations, advanced degree, and certification programs. Two American law schools, Loyola University Chicago and Chicago-Kent College of Law, offer LL.M. Programs in the family law field. A third, Hofstra University School of Law, will commence its program offering an LL.M. in Family Law in 2006. In addition, FLER Project members endorsed the creation of linkages among teaching institutions and between teaching institutions and clinicians as methods for bridging the gap between students and professionals and among the professionals who are already working with the same families but are failing at working together.

\section{CONCLUSION: WHAT DO WE HOPE TO ACCOMPLISH? PRINCIPLES AND RECOMMENDATIONS}

The FLER Project argues that a reorientation of family law teaching is overdue. The new family law curriculum would present the bedrock doctrinal and constitutional principles of the case law, but it would put these rulings in their historical and sociological context. Then, it would explicitly link that context to the pressures facing American families and American family law today. This new family law would then venture beyond content and context to deal explicitly with lawyers' conduct - the ethical issues lawyers face and the response to their behavior offered in studies like Sarat and Felstiner's Divorce Lawyers and their Clients. ${ }^{162}$ Finally, the new family law curriculum would emphasize the acquisition of a broad range of skills in listening, counseling, communicating, managing, and more.

Three overall principles have guided the construction of this Report:

1. We encourage family law professors to shift from a course structure based on doctrine to one based on a hypothetical family or families and the issues they face over time.

2. We stress the interdisciplinary models of contemporary family law practice.

3. We emphasize the need to teach the role and methodologies of ADR, which has widely displaced traditional litigation in the family courts.

We have tried to document the radical changes in family law in the last generation. The challenges facing today's family lawyers run the gamut from drafting complex prenuptial agreements, to preparing QDROs, to working successfully with mediators and custody evaluators. The following list summarizes many additional recommendations from FLER Project participants:

* Refocus the teaching of legal content to emphasize vital (and understressed) areas, especially IPV and child maltreatment

* Incorporate discussions of legal policy, cultural diversity, and international and comparative law into family law classes

* Focus on financial issues and help students to develop skills in basic financial counseling 
* Foster professionalism, stressing both ethics and civility

* Prepare students for the impact of the pro se explosion on the family courts

* Prepare students to educate the public about the family law system

* Teach students to be active listeners, to handle emotional content, to set professional boundaries, and to manage cases and their law offices effectively

* Teach students about lawyer self-care

* Increase efforts to recruit students who want to practice family law

* Implement family law certification and focus programs

Although each of these points is discussed in this Report, we view this document as merely the down payment on an ongoing effort to effect family law education reform. The FLER Project will next develop teaching modules to illustrate, incorporate, and extend the curricular recommendations of this Report. We anticipate that these modules will serve as the keystones for our proposed reorganization of family law teaching.

While our recommendations are aimed principally at law professors and law school deans, we recognize that the interdisciplinary model that characterizes so much of contemporary family law practice implicates colleagues in other professions whose assistance is essential if we are to carry out these reforms. We encourage professionals in many fields who work toward the resolution of family disputes to support the new directions in family law education this Report has set out. This Report is based on the considered wisdom of several truly interdisciplinary professional groups. In the same spirit, we encourage the bench and bar who toil in the family law field and whose representatives also contributed to these recommendations to support this Report in their respective communities.

None of this is impossible. Much of what is missing in contemporary family law courses can be borrowed and adapted from other fields. If the enthusiasm of the FLER Project's participants is any gauge, this is a challenge that can be met. 


\section{Family Law Education Reform Project}

Snapshots of our (Legal \& Academic) Family 


\section{What are Law Students}

reading in our Family Law Texts? 


\section{Let's Throw a Ple Chart at an Illustrative Sample of Eight Texts:}

- Cases \& Statutes

- Law Reviews/Journals

History/Theory

- Practical Legal

Inclusion of Social Science

material

- Reference to Social Science

material

Miscellaneous 


\section{Raw Numbers \{combinee 9,333 pages\}}

$$
\begin{aligned}
& 3+75 \\
& 575 \\
& 775 \\
& 254 \\
& 561-25 \\
& 553-25
\end{aligned}
$$

Miscolangers

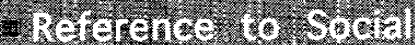

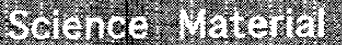

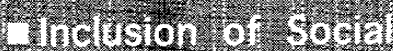

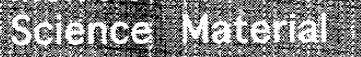

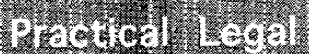

1. Whatheras

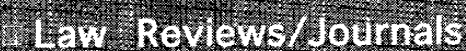

Cases s strutes 


\section{What's in Miscellaneous? $\{341$ pages, or $4 \%$ of total\}}

i. Stitistics

- Perigiticals

- Personal Case misteries

4. 56.

- Math o. Esenorics

1. Wom whers

5. Meratire?

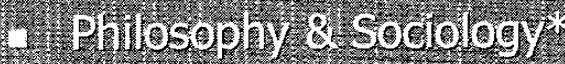

- Blibios relly

- Pellee Reis or Legal Msm.

t. Religious text

Tinelided in only 1 text

\section{Pages}

75

62

37.

305

45

2.

4855

4 . 5

2275

1535

5 


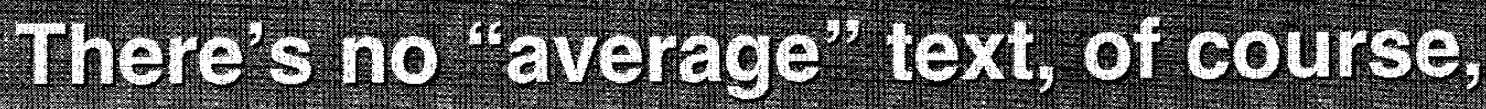 but what's in the "mean" text?}

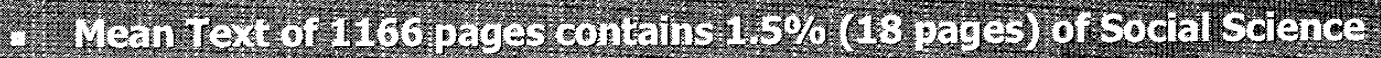

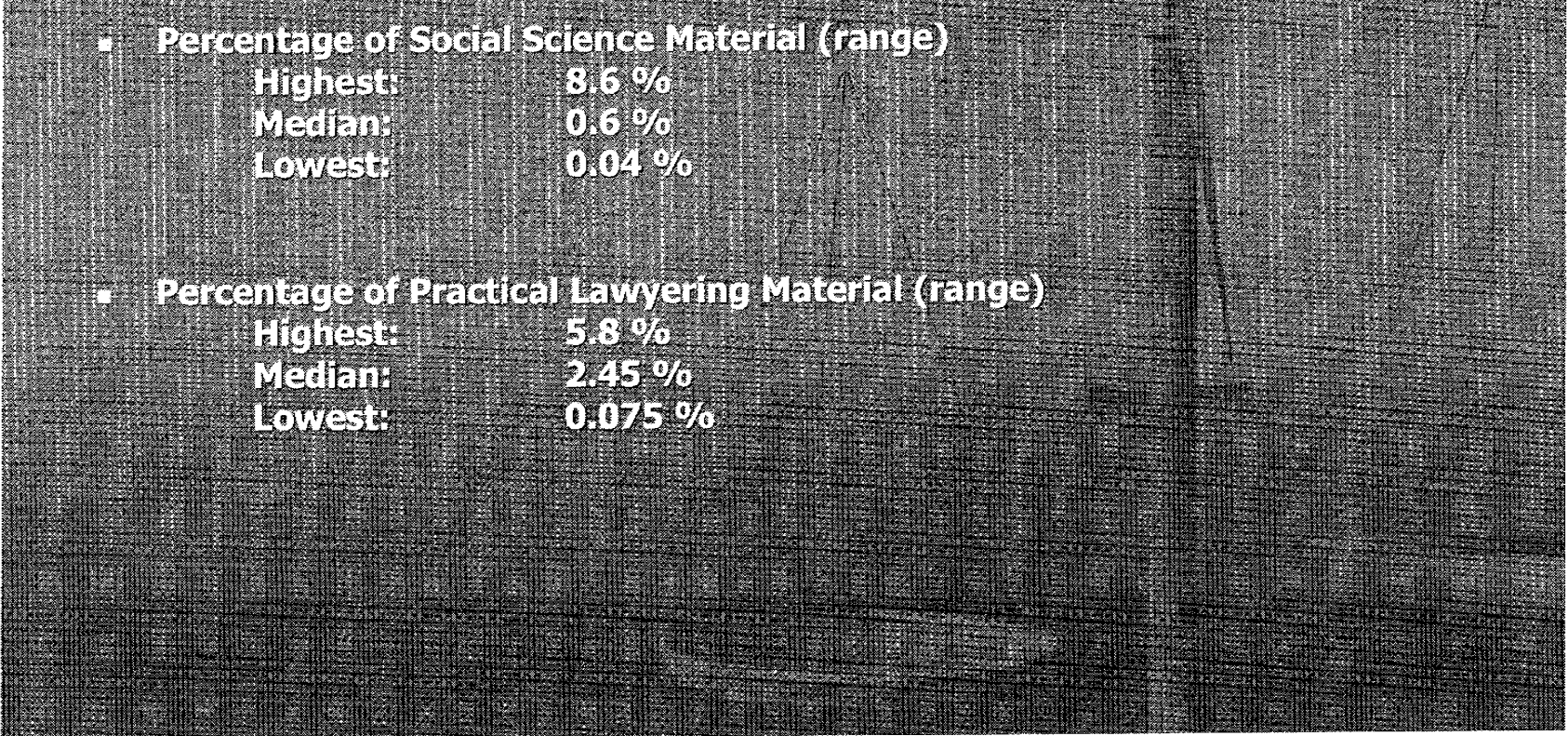


Years of Experience in Fanily Law by Response to Skills, Knowledge, Attitude/Attribute Closed-ended, Quostions

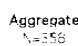

30 or more years
$y=n$

20 or mors, less than 30

10 or more, less than 20

$$
\text { Less than } 70 \text { years }
$$

Skill s "extremely irportant" to effective family : aw practice.

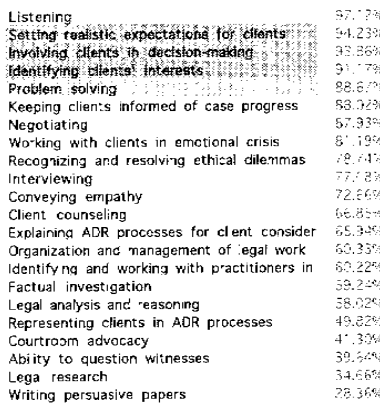

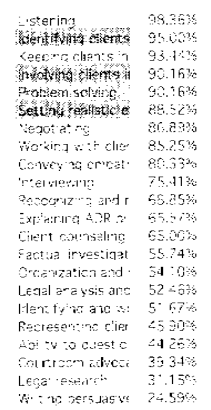
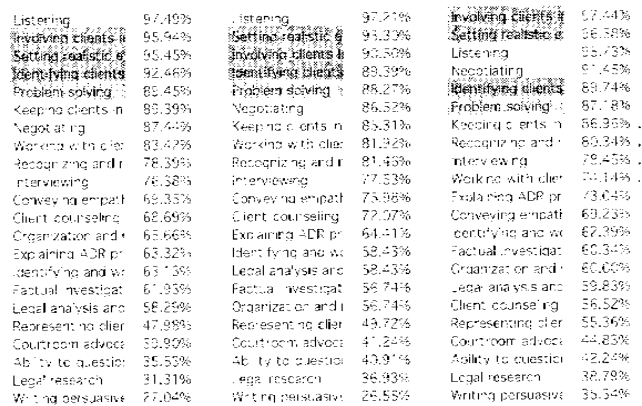

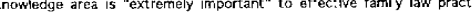
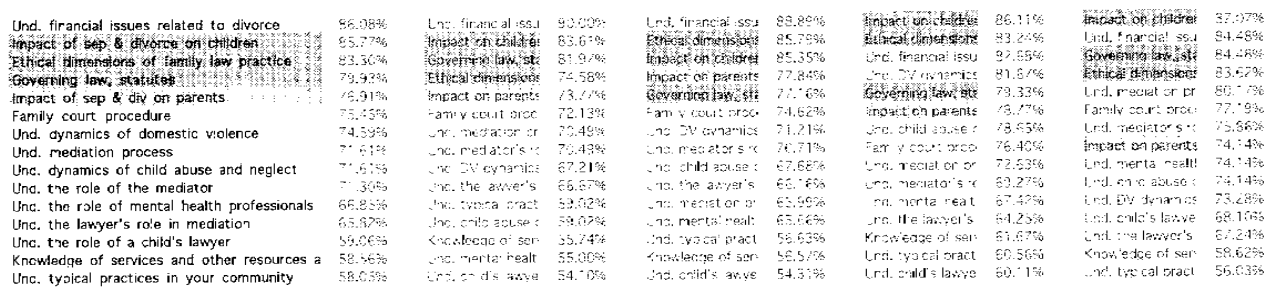

Attribute is effrctive in all cases n family law practice

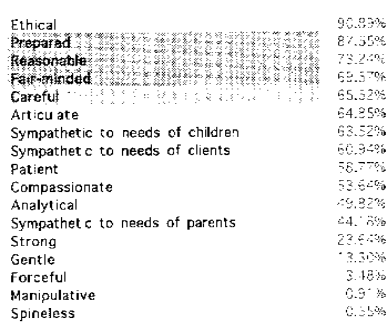

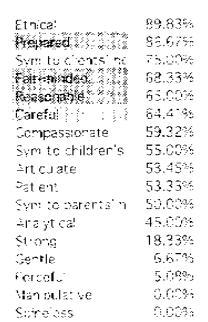

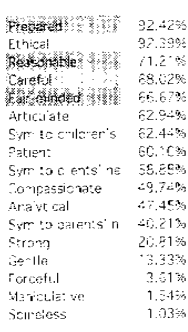

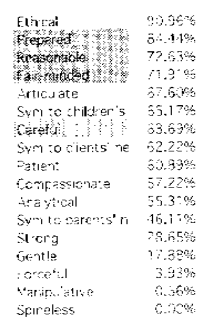

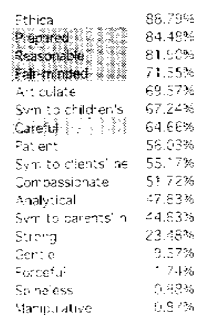




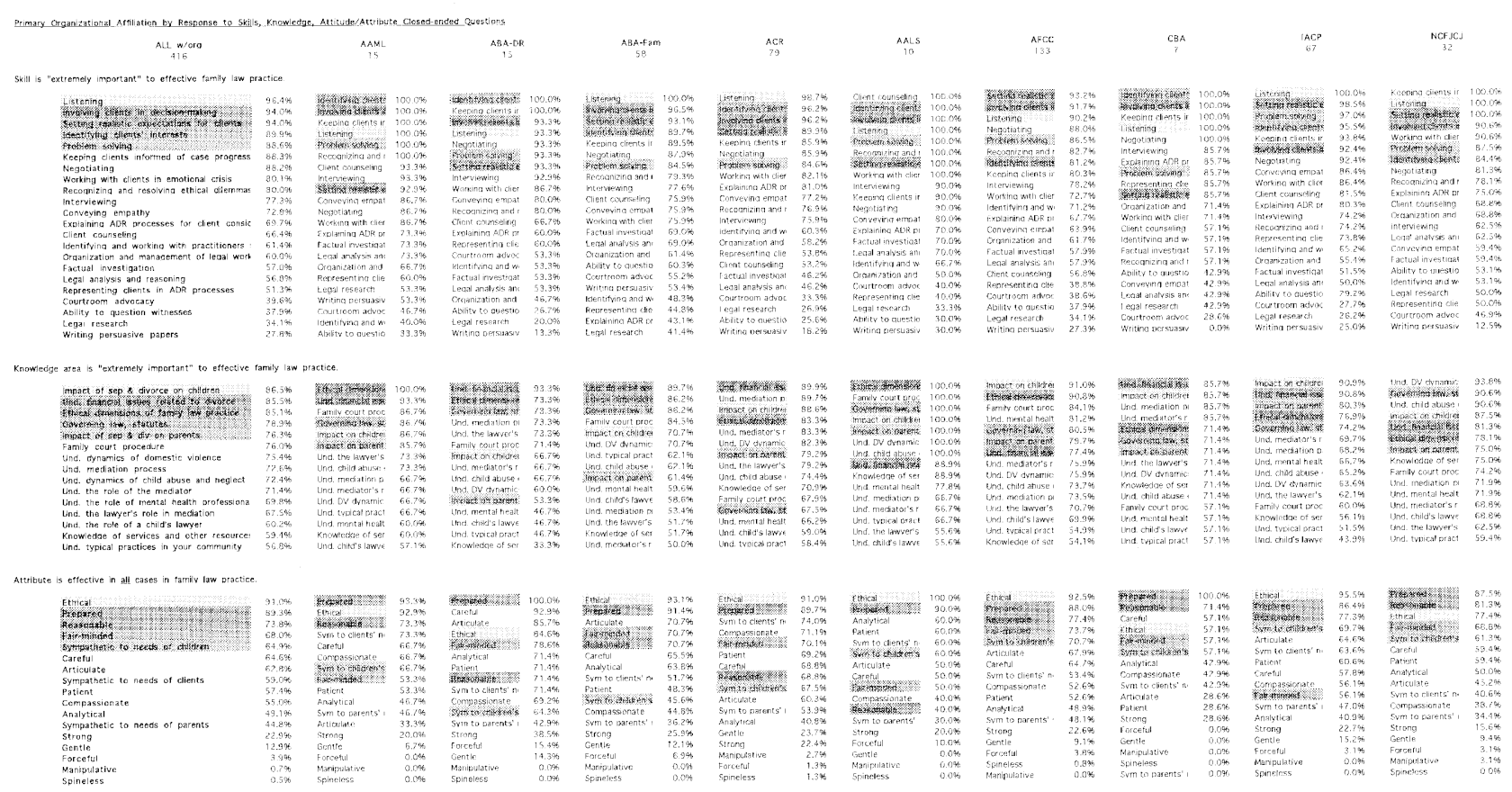



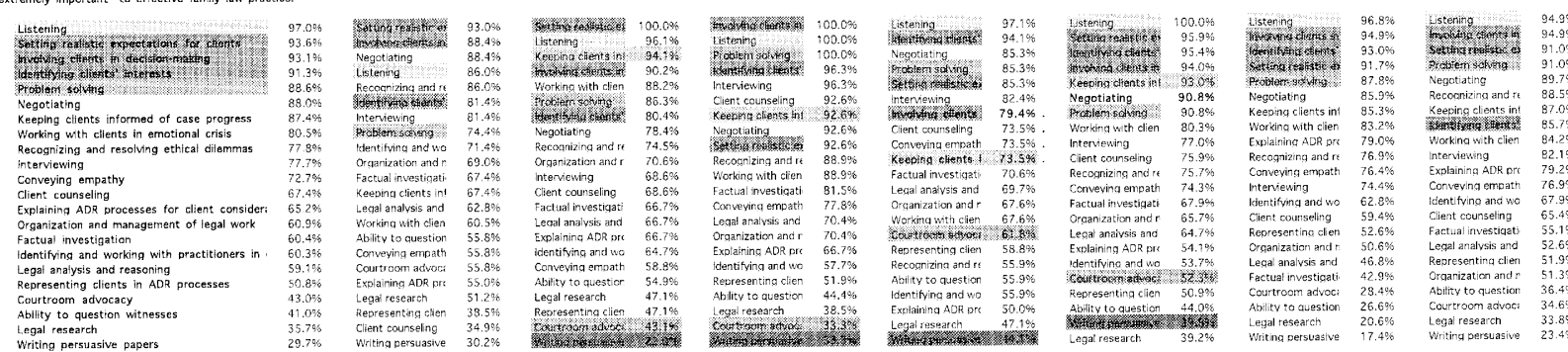

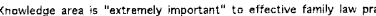
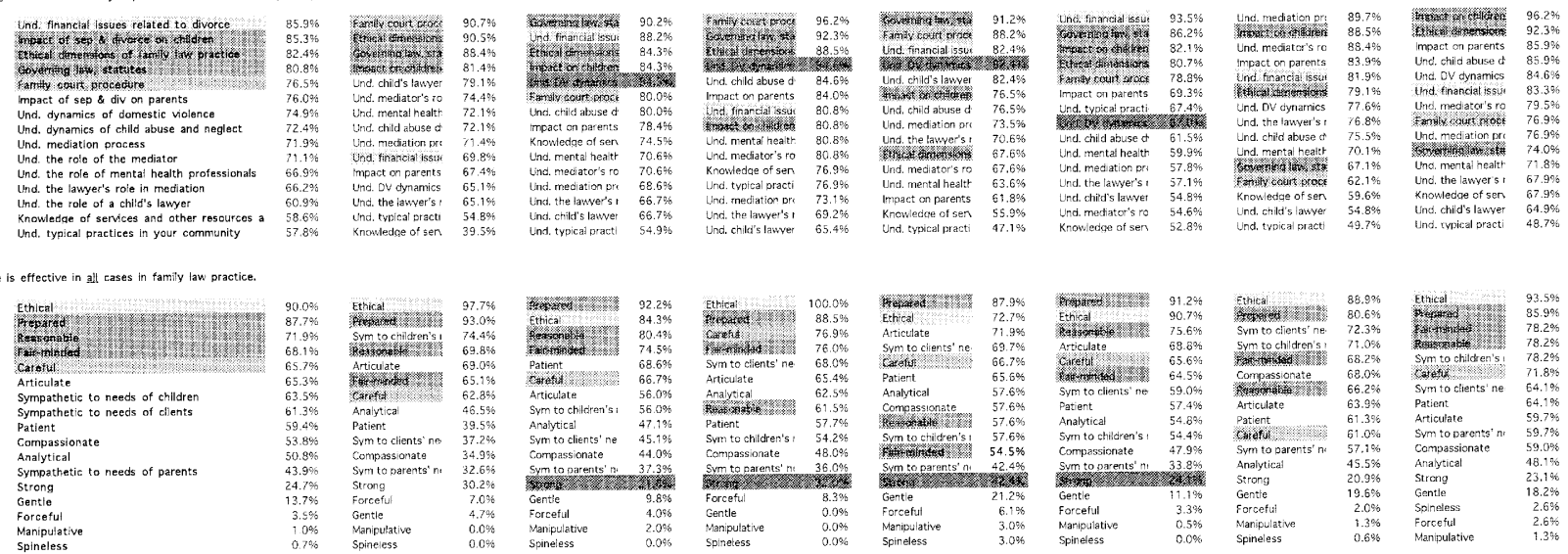


\section{NOTES}

1. Mary E. O'Connell is Professor of Law at Northeastern University School of Law. J. Herbie DiFonzo is Professor of Law at Hofstra University School of Law.

2. The Reporters acknowledge the extensive support provided by Andrew I. Schepard, Professor of Law and Director of Hofstra University's Center for Children, Families and the Law, and Peter Salem, Executive Director of the Association of Family and Conciliation Courts. The support of the Johnson Foundation, which made its Wingspread facility available for 3 days of intensive discussions, is also gratefully noted. Additional funding for the FLER Project has been kindly provided by the JAMS Foundation, a nonprofit corporation providing financial assistance for conflict resolution initiatives in the public interest. We also thank the law students who have contributed to this Report: at Hofstra Law School, Heather Abissi, Sharon Clarke, Alexis Collentine, Danielle Passano, and Marion Perry; and at Northeastern University School of Law, Sarah Brady Lay and Daniel Miller.

3. The group included law professors, family court judges, practicing lawyers, mental health professionals, mediators, and others. A list of the project's participants may be found at http://www.hofstra.edu/pdf/ law_FLER_report_101405.pdf (last visited May 18, 2006).

4. Public fora for presentation, discussion, and development of the FLER Project have included the following: AFCC Conference, San Antonio, TX (May 2004); Hofstra University/AFCC Conference, Hempstead, NY (Nov. 2004); AALS Workshop, Alternative Dispute Resolution and Juvenile \& Family Law Sections, San Francisco, CA (Jan. 2005); Wingspread Conference, Racine, WI (Mar. 2005); AFCC Conference, Seattle, WA (May 2005).

5. Note that this Report discusses improvements to a family law curriculum, encompassing the range of family law courses a law school might offer. We do not discuss the selection and sequencing of courses within that curriculum.

6. Published in 2002, the Principles are a comprehensive effort to synthesize the best practices of, and provide a normative template for, American family law in the 21 st century. American Law Institute, Principles of the Law of Family Dissolution: Analysis and Recommendations (2002) [hereinafter ALI Principles].

7. ALI Principles, Introduction to Topic 1, "The Current Legal Context", 1.

8. ALI Principles, 6.

9. See, for example, the California statute mandating mediation in child custody disputes. CAL. FAM. CodE $\S$ 3161 (West 2004). The provision states that one goal of mandatory mediation is to develop an agreement that assures the child close and continuing contact with both parents. This contact goal derives from social science literature. It was prominently argued in the work of Dr. Judith Wallerstein and Dr. Joan Berlin Kelly, whose longitudinal study of 60 divorced families was the first of its kind. Their research led them to suggest that the children who are most successful, emotionally and practically, after their parents' divorce are those who maintain a warm and continuing relationship with both parents. See Judith S. WALlerstein \& JoAn Berlin Kelly, Surviving the Breakup: How Children and Parents Cope with Divorce (1980). This work challenged a theory prominent in the 1970s and 1980s. See JosePh Goldstein ET AL., Beyond the Best Interests of THE CHILD (1973). Goldstein et al. had argued that what a child of divorce needs most is an uninterrupted relationship with her psychological parent.

Wallerstein and Kelly's work has itself been expanded by other empirical studies, suggesting that contact may not be beneficial if it means subjecting the child to very high continuing parental conflict. See, e.g., E. MavIS Heatherington \& John Kelly, For Better or For Worse: Divorce Reconsidered (2002); Eleanor E. Maccoby \& Robert H. Mnookin, Dividing the Child: Social and Legal Dilemmas of Custody (1992). Contact, however, seems to dominate in the law of California.

10. Michael Grossberg, Balancing Acts: Crisis, Change, and Continuity in American Family Law, 1890-1990, 28 IND. L. REv. 273, 308 (1995) (noting that family conflict must be "expressed through particular rules and procedures that grant the law its legitimacy").

11. One common division differentiates "family" law from "juvenile" law. The former generally encompasses such issues as cohabitation, marriage, adoption, divorce, spousal property rights, alimony, custody, and child support. The latter covers delinquency, child abuse and neglect, and foster care, among other topics. However, in a unified family court, all of these issues may fall within the purview of a single judge, and a family law attorney would be expected to handle the gamut. The FLER Project's working definition of "family law" includes, at a minimum, all of the topics just listed. For an excellent introduction to the unified family court concept, see Barbara A. Babb, Where We Stand: An Analysis of America's Family Law Adjudicatory Systems and the Mandate to Establish Unified Family Courts, 32 FAM. L.Q. 31 (1998).

12. American Bar Association, ABA-Approved Law Schools, http://www.abanet.org/legaled/approvedlawschools/ approved.html (last visited May 31, 2005).

13. Many law schools have more than one family law professor. 
14. As an adjunct to the FLER Project, Professor DiFonzo's students reviewed a number of standard family law casebooks. (See results at Appendix A to this Report.) A FLER Project survey instrument was also compiled, distributed, and analyzed. Survey respondents included law professors, family lawyers, mediators, custody evaluators, and law students. (See survey results at Appendix B to this Report.) Although this Report reflects both the survey results and the casebook analysis, we viewed our central task as capturing and ordering the yield of the five working sessions, some running multiple days, that are listed supra at note 4.

15. No effort was made to effect a scientific selection. Professor DiFonzo simply requested that his students pull and examine the first eight family law casebooks they found on his shelves.

16. Of the remaining pages, $6 \%$ were drawn from law reviews, $6 \%$ could be characterized as history/theory, $3 \%$ contained practical legal material, $2 \%$ contained references to social science data, and $4 \%$ consisted of miscellaneous material. See DiFonzo Presentation 1 in Appendix B. (Note that the percentages refer only to the casebook review. No study was made of how law professors actually use their class time.)

17. An excellent discussion of this process appears in Sarah H. Ramsey \& Robert F. Kelly, Social Science Knowledge in Family Law Cases: Judicial Gate-Keeping in the Daubert Era, 59 U. Mrami L. Rev. 1 (2004). For a recent controversial application of social science theory by a state supreme court, see In re Marriage of LaMusga, 88 P.3d 81 (Cal. 2004). This case is discussed infra at note 56.

18. See supra note 12 .

19. Dependable numbers are hard to identify, but it is commonly asserted that fewer than $10 \%$ of family law cases involve litigation of any issue of substance. See, e.g., FAMILY LAW In Action: A ReAder 235 (Margaret F. Brinig et al., eds., 1998) ("[through] the process of negotiation... some $90 \%$ of all divorce matters are resolved.”). See also Marygold S. Melli et al., The Process of Negotiation: An Exploratory Investigation in the Context of No-Fault Divorce, 40 Rutgers L. Rev. 1133 (1988). "Over the past two decades, many studies, including ours, have found that the predominant mode of dispute resolution is not litigation but negotiation. Of the 349 files examined in the first phase of our study, only 32 involved a dispute between parties that had to be settled by a judge." Id. at 1142. This small empirical study found a litigation rate of 9\%. See also Andrew Schepard's comprehensive study of child custody dispute resolution, in which he asserts that "[t]he great majority of divorcing parents reach agreement on a parenting plan with little or no outside intervention." ANDREW I. Schepard, Children, Courts, and Custody: Interdisciplinary Models for Divorcing Families 31 (Cambridge University Press, 2004).

20. For an intriguing argument about whether these professionals have too much power, compare Timothy M. Tippins \& Jeffrey P. Wittmann, Empirical and Ethical Problems with Custody Recommendations: A Call for Clinical Humility and Judicial Vigilance, 43 FAм. Cт. Rev. 193 (2005) with Nicholas Bala, Tippins and Wittmann Asked the Wrong Question: Evaluators May Not Be "Experts," But They Can Express Best Interests Opinions, 43 FAM. CT. Rev. 554 (2005). For a scholarly and comprehensive treatment of the issue of the use of social science experts in the family courts, see Ramsey \& Kelly, supra note 17.

21. For an in-depth description of this relatively new approach to negotiation in divorce, see PaULINE H. Tesler, Collaborative Law: Achieving Effective Resolution in Divorce without Litigation (American Bar Association Section of Family Law, 2001). For a critique of collaborative law, see Mary E. O'Connell, Book Review, 40 Fam. Cт. Rev. 403 (2002); John Lande, Possibilities for Collaborative Law: Ethics and Practice of Lawyer Disqualification and Process Control in a New Model of Lawyering, 64 OHIO ST. L.J. 1315 (2003); Julie Macfarlane, The Emerging Phenomenon of Collaborative Family Law (CFL): A Qualitative Study of CFL Cases, at http://www.justice.gc.ca/en/ps/pad/reports/2005-FCY-1/notes.html.

22. See Ramsey \& Kelly, supra note 17.

23. In many law schools, students may elect courses that focus on negotiating skills, or on what is usually termed ADR - alternative dispute resolution. Participants in the FLER Project agreed that teaching these skills outside of the family law course should suffice, with two provisos: (1) any student taking family law should be strongly urged to take negotiation and ADR courses as well and (2) family law professors should work with their ADR colleagues to provide a family law setting for at least some of the problems and examples used in the ADR courses.

24. See "Domestic Violence" text infra at notes 79-92.

25. See, e.g., Mark Neal Aaronson, Thinking Like a Fox: Four Overlapping Domains of Good Lawyering, 9 Clinical L. Rev. 1, 6-7 (2002). "The result [of reliance on case method teaching] is a cognitive bias that recurringly under-emphasizes the nonlegal, intellectual or emotive dimensions of a problem situation." Id.

An excellent, comprehensive document on needed change in legal education is available from the Clinical Legal Education Association (CLEA) and its Best Practices Project. The August 31, 2005 edition of CLEA's "Best Practices for Legal Education" can be found at http://www.professionalism.law.sc.edu/news/html (last visited Sept. 5, 2005) [hereinafter CLEA Best Practices]. 
26. American Bar Association Section on Legal Education and Admissions to the Bar, Legal Education and Professional Development: An Educational Continuum, Report of the Task Force on Law Schools and the Profession: Narrowing the Gap 284 (1992) [hereinafter MacCrate Report].

27. CLEA Best Practices, supra note 25, at 2. "Introduction to the Best Practices Project," draft of Aug. 31, 2005.

28. While there is no official "family law canon," that is, no set of topics that must be covered by a family law curriculum, most of the following topics are included in commercial casebooks and, we would assume, in many family law courses:

Historical background

Marriage and marriage alternatives, including cohabitation and the role of contract in premarital, marital, and nonmarital unions.

Legal obligations and benefits of marriage and other family relationships

Procreation and paternity, including support obligations and parental access

Adoption

Family court jurisdiction and jurisdictional issues (UCCJEA and PKPA)

Divorce and dissolution of marriage-like unions, including annulment

Spousal and child support upon dissolution, including modification

Division of property at dissolution, including valuation, pension, and tax issues

Child custody and visitation, including modification and relocation

Legal ethics, including fee issues

There are, of course, many variations among courses and professors. Indeed, we would expect variation, given that a stark feature of contemporary family law is its disarray, both conceptually and institutionally. See, e.g., Geoffrey C. Hazard Jr., Foreword to the ALI Principles of the Law of Family Dissolution: Analysis and Recommendations xiii (American Law Institute 1997) (Proposed Final Draft Part I) (referring to the "current disarray in family law”). But see Jill Elaine Hasday, The Canon of Family Law, 57 StAn. L. Rev. 825 (2004) (elaborating a canonical ordering of ways of thinking about family law shared by scholars, legislators, and judges).

29. Robert M. Moroney, U.S. Dep't of Health and Human Serv., Families, Social Services, and Social Policy: The Issue of Shared Responsibility 50 (1980). The business school model provides some pedagogical alternatives. See, e.g., Carrie J. Menkel-Meadow, When Winning Isn't Everything: The Lawyer as Problem Solver, 28 Hofstra. L. Rev. 905, 915 (2000) (suggesting that business schools have bested law schools in teaching "counseling, interviewing, case valuation (quantitative skills in statistics and economics), negotiation, planning, meeting facilitation, mediation, decision making, and leadership."). One caveat would reflect the soul searching business schools have recently engaged in on the issue of ethics in light of corporate scandals such as the collapse of Enron. See, e.g., Liz Willen, Seeking to Shame: Scandals Turn up Heat on Business Schools to Accept Responsibility and Incorporate More Ethics into Courses, Pittsburgh Post-Gazette, Mar. 23, 2004, at C-10.

30. Margaret F. Brinig \& Carl E. Schneider, Invitation to Family Law: Principles, Process, and Perspectives iii (Teacher's Manual, $2 \mathrm{~d}$ ed. 2000) (the historical summaries, along with detailed financial profiles, are set out at pp. 478-502).

31. Id. at iii.

32. See generally Nina Bernstein, The Lost Children of Wilder: The Epic Struggle to Change Foster CARE (2001).

33. This estimate comes from Professor Barbara Babb, from the year 2002. See Barbara A. Babb, Where We Stand Redux: Another Look at America's Family Law Adjudicatory Systems, 35 FAM. L.Q. 628, 632 (2002) (Chart $10)$.

34. SCHEPARD, supra note 19 , at 4 . Schepard provides an articulate and passionate plea for the wider adoption of the unified family court model. See id. at 175-84.

35. See discussion in SchePard, supra note 19, at 115-18.

36. Professor Babb noted 13 such states in 2002. See Barbara Babb, Problem Solving Courts: From Adversarial Litigation to Innovative Jurisprudence, 29 FordHAM URB. L.J. 1929, 1945 (2002).

37. Id.

38. For example, Middlesex County, the most populous county in Massachusetts.

39. For example, California. See CAL. FAM. CodE $\S 3161$ (West 2005).

40. For a strong endorsement of unified family courts, see SCHEPARD, supra note 19; Babb, supra note 36, at 1943-49. For a word of caution, see Anne H. Geraghty \& Wallace J. Mlyniec, Unified Family Courts: Tempering Enthusiasm with Caution, 40 FAM. CT. Rev. 435 (2002).

41. It is important to stress, however, that only a tiny minority of cases proceed to a formal trial. See Melli et al., supra note 19 . Estimates usually suggest that only about $10 \%$ of cases are tried. Writing in 1988 , researchers 
Marygold S. Melli, Howard S. Erlanger, and Elizabeth Chambliss stated that "over the past two decades, many studies, including ours, have found that the predominant mode of dispute resolution is not litigation but negotiation." Id. at 1142 .

42. See Meyer Elkin, Postdivorce Counseling in a Conciliation Court, 1 J. DrvorCE 55 (1977).

43. See Isolina Ricci, Court-based Mandatory Mediation: Special Considerations, in JAY Folberg ET AL., Divorce and Family Mediation: Models, Techniques, and Applications 398 (2004).

44. Id. at 399.

45. See, e.g., the excellent chapter by Nancy A. Welsh, Reconciling Self-Determination, Coercion and Settlement in Court Connected Mediation, in Folberg ET AL., supra note 43, at 420-23.

46. See, e.g., Harold I. Abramson, Mediation Representation: Advocating in a Problem Solving Process (2004); John W. Cooley, Mediation Advocacy (NITA Practical Guide Series 2002).

47. See TESLER, supra note 21.

48. On the topic of cooperative law, see John Lande \& Gregg Herman, Fitting the Forum to the Family Fuss: Choosing Mediation, Collaborative Law or Cooperative Law for Negotiating Divorce Cases, 42 FAм. Ct. REv. 280 (2004).

49. See, e.g., Penelope E. Bryan, Killing Us Softy: Divorce Mediation and the Politics of Power, 40 Buff. L. REv. 441 (1992).

50. Compare, e.g., Barbara J. Hart, Gentle Jeopardy: The Further Endangerment of Battered Women and Children in Custody Mediation, 7 Mediation Q. 317 (1990), with Kara C. Utzig, Entering the Debate on Spousal Abuse Divorce Mediation: Safely Managing Divorce Mediation when Domestic Violence is Discovered, 7 Buff. Women's L.J. 51 (1999). For a more recent, highly nuanced and especially thoughtful review of this issue, see Nancy Ver Steegh, Yes, No and Maybe: Informed Decision Making About Divorce Mediation in the Presence of Domestic Violence, 9 WM. \& MARY J. WOMEn \& L. 145 (2003).

51. A treasure trove of information about relevant professional standards is available through links from the AFCC Web site, http://www.afccnet.org.

52. A good presentation of the "gladiator" model of divorce representation is RAOul LiONEL FeLDER, Divorce: The Way Things Are, Not the Way Things Should Be (1971).

53. It is clear that a lawyer's professional responsibility includes consideration of ADR processes. See, e.g., American Academy of Matrimonial Lawyers, Bounds of Advocacy: Goals for Family Lawyers, http:// www.aaml.org/files/public/Bounds_of_Advocacy.doc (last visited Aug. 16, 2005) [hereinafter Bounds of Advocacy] (Sec. 1.4: "An attorney should be knowledgeable about different ways to resolve marital disputes, including negotiation, mediation, arbitration and litigation."; Sec. 1.5: "An attorney should attempt to resolve matrimonial disputes by agreement and should consider alternative means of achieving resolution.") The ABA Model Rules of Professional Conduct state that "when a matter is likely to involve litigation, it may be necessary under Rule 1.4 to inform a client of forms of dispute resolution that might constitute reasonable alternatives to litigation." MODEL RULES OF Prof'L CONDUCT R. 2.1, cmt. 5, available at $\mathrm{http}: / /$ www.abanet.org/cpr/mrpc/rule_2_1_comm.html (last visited May 9, 2006).

54. See Part III(B)(2) of this Report.

55. See, for example, the sources cited in Ramsey \& Kelly, supra note 17.

56. See, e.g., In re Marriage of LaMusga, 88 P.3d 81 (Cal. 2004) (The trial court adopted a psychologist's view that two children needed frequent, in-person contact with their noncustodial parent despite (or perhaps because of) their weak relationship with him. The court held that, if the mother, who had had custody of the children since the divorce, moved from California to Ohio to be near her extended family, the court would transfer custody of the children to the father).

57. See supra notes 10-27 and accompanying text. These non-legal professionals may be psychologists, psychiatrists, social workers, or members of other disciplines. Some cases will involve multiple mental health professionals playing various roles.

58. Marsha Kline Pruett \& Tamara D. Jackson, The Lawyer's Role During the Divorce Process: Perception of Parents, Their Young Children, and Their Attorneys, 33 FAM. L.Q. 283, 303 (1999). "The predominant attitude of such parents was that attorneys served an antagonistic role in divorce and contributed to prolonged feelings of hardship and frustration." Id.

59. Bounds of Advocacy, supra note 53, at Preliminary Statement, note 1 (citing studies). The Bounds of Advocacy was recently endorsed as a practice guide for Florida family law attorneys by the Executive Council of the Family Law Section of the Florida Bar. See http://www.familylawfla.org. On issues generated by the pro se explosion in family court, see Steven K. Berenson, A Family Law Residency Program?: A Modest Proposal in Response to the Burdens Created by Self-Represented Litigants in Family Court, 33 Rutgers L.J. 105, 107-12 (2001); Jona Goldschmidt, How Are Courts Handling Pro Se Litigants?, 82 Judicature, July-Aug. 1998, at 14; 
Johnny Diaz, New Order: Solo in the Court Do-It-Yourself Lawyering Inspired by TV, Lack of Funds, BosTON Globe, July 31, 2003, at 6; Jodi Wilgoren, Divorce Court Is Now in Lawyer-Free Session, N.Y. Times, Feb. 9, 2002, at A12.

60. See Berenson, supra note 59, at 105 (noting that "the high cost of legal services and antipathy to lawyers are also likely contributors to the rising number of self-represented family law litigants").

61. See Model Rules of Prof'L Conduct, supra note 53, at R. 4.3 (during the course of a lawyer's representation of a client, "the lawyer shall not give legal advice to an unrepresented person, other than the advice to secure counsel."); ABA, The Wingspread Report and Action Plan: High-Conflict Custody Cases: Reforming the System for Children, 39 FAM. CT. REv. 146, 151 (2001) ("The legal profession should develop protocols for working with unrepresented opposing parties in high-conflict cases.”).

62. See Berenson, supra note 59, at 131 ("Unbundling, also known as limited legal assistance, simply refers to legal representation that involves some, but not all of the services traditionally thought to be included within full-service representation."). An excellent introduction to the subject of unbundling by one of its original and most articulate proponents is Forrest S. Mosten, Unbundling Legal Services and the Family Lawyer, 28 FAM. L.Q. 421 (1994).

63. See Berenson, supra note 59 , at $132-33$.

64. Id. at 133 .

65. Id. at 134. See also Julie Macfarlane, Experiences of Collaborative Law: Preliminary Results from the Collaborative Lawyering Research Project, 2004 J. DisP. Resol. 179, 180-81 (2004) ("Collaborative law eschews litigation in favor of a formally contracted negotiation process directly involving both lawyers and their clients, and sometimes incorporating other types of relevant professional expertise (for example, financial advice, forensic accounting, therapeutic and counseling services for both adults and children)").

66. Some law schools and law professors are already bringing the pro se explosion home, so to speak. At Southern Illinois University, students teach a two-session self-help class to interested area residents who are about to embark on a pro se divorce. The students bone up on a variety of nuts and bolts topics, like service of process, and are able to explain them to the potential litigants. No fee is charged for this service, nor has the professor needed funding to conduct these informational sessions.

67. Indeed, one could argue convincingly that little has changed since the path-breaking work of Jacobus TenBroek, California's Dual System of Family Law: Its Origin, Development, and Present Status (Part I), 16 Stan. L. Rev. 257 (1964); California's Dual System of Family Law: Its Origin, Development, and Present Status (Part III), 17 Stan. L. Rev. 614 (1965). TenBroek argued that the courts' treatment of the middle class and the poor deviated so dramatically that, in effect, two entirely separate systems of family law were being applied.

68. Zablocki v. Redhail, 434 U.S. 374 (1978) is a case about an unmarried, poor, teenage father and can only be taught if that fact is understood. Moore v. City of East Cleveland, 431 U.S. 494 (1977) opens students' eyes to the alternative family forms that are far more common in poor than in wealthy families. But in many cases demographic information is edited out, or not included by the courts to begin with. Who knows the race and economic status of the parties in Lehr v. Robertson, 463 U.S. 248 (1983), Thronson v. Thronson, 810 P.2d 428 (Utah App. 1991), or Parham v. J.R., 442 U.S. 584 (1979)?

69. This is clearly the case with the delinquency population: "Overrepresentation of minority youth in the juvenile justice system is also a national problem. For example, in 1997 minorities made up about one-third of the juvenile population nationwide but accounted for nearly two-thirds of the detained and committed population in secure juvenile facilities." Commonwealth of Massachusetts, Executive Office of Public Safety Programs Division, Massachusetts Juvenile Justice Data and Information 22 (2004), available at http:// www.mass.gov/Eeops/docs/programs/fjj/mass_juvenile_justice_data_version_july05.doc. This report further notes that "[i]n 2003, minority children made up approximately $52 \%$ of the children in foster care but only made up $25 \%$ of the total population under 18 -years-old." Id. at 72.

70. Some recent empirical work on courts' adoption of mandatory divorce education programs provides a rare glimpse into the racial composition of divorce court litigants. Jack Arbuthnot surveyed 165 counties in states throughout the United States. Of those, 155 identified their client population as mostly White, with four indicated populations that were mostly non-White. Forty-one counties reported mixed populations, seemingly indicating that some respondents provided more than one response. See Jack Arbuthnot, A Call Unheeded: Courts' Perceived Obstacles to Establishing Divorce Education Programs, 40 FAм. Cт. Rev. 371 (2002). The claim here is not that poor people or members of racial minorities do not divorce. The claim is that the median income and the racial identity of the parties in courts that hear primarily divorce cases is substantially different from that of courts that hear primarily delinquency and dependency cases. See also http:/www.census.gov/population/www/ socdemo/marr-div/p70-97-tab01.html for data on the Marital History for People 15 Years and Older by Age, Sex, Race and Ethnicity (2001). 
71. While this distinction obtains in some states, in fact, American courts parcel out jurisdiction over cases involving family relationships in myriad and inconsistent ways.

72. Medicaid is a federal/state partnership, providing medical insurance for certain low-income individuals and families. See 42 U.S.C. $\S \S 1396-1396 u$ (2005).

73. "SCHIP" is the State Children's Health Insurance Program, enacted by the Balanced Budget Act of 1997 (P.L. 105-33), and now codified as Title XXI of the Social Security Act, 42 U.S.C. $\S \S 1397 a a-1397 j$ (2005).

74. This is the number reported by the U.S. Census Bureau in August 2005, at http://www.census.gov/PressRelease/www/releases/archives/income_wealth/005647.html (last visited Sept. 25, 2005).

75. Reporting in August 2005, the U.S. Census Bureau put the poverty rate for the U.S. population under age 18 at $17.8 \%$ (13 million children), poverty for those aged $18-64$ at $11.3 \%$, and poverty for those aged 65 and older at $9.8 \%$. Id. This compares to child poverty rates in Denmark of $2.4 \%$, France $7.5 \%$, and the United Kingdom 15.4\%. See UNICEF Innocenti Research Centre, Florence, Italy, Report Card No. 6: Child Poverty in Rich Countries, at http://www.un-ngls.org/UNICEF-child-poverty-in-rich-countries-2005.pdf (2005).

76. Convention on the Rights of the Child, 28 I.L.M. 1448 (1989) (adopted Nov. 28, 1989, entered into force Sept. $2,1990)$. A good, brief introduction to this important document can be found in Douglas E. Abrams \& SaraH Ramsey, Children and the Law: Doctrine, Policy and Practice 96-98 (2000).

77. Hague Convention on the Civil Aspects of International Child Abduction, Oct. 25, 1980, 51 Fed. Reg. 10,494 (March 26, 1986). This Convention has been ratified by 54 countries, http://hcch.e-vision.nl/ index.php?act $=$ conventions. . $t$ tatus\& $\mathrm{cid}=24$.

78. Indeed, family law materials with an international perspective are beginning to appear on the market. See, e.g., Barbara Stark, International Family Law: An Introduction (2005); D. Marianne Blair \& Merle H. Weiner, Family Law in the World Community: Cases, Materials, and Problems in Comparative AND INTERNATIONAL FAMILY LAW (2003).

79. By domestic violence we mean intimate partner violence (IPV), as distinguished from child maltreatment (abuse and neglect), which is treated in the following subsection. IPV may be the preferable term, because it "encompasses a broad array of relationships. As used here, IPV is violence committed by a spouse, ex-spouse, or current or former boyfriend or girlfriend. It can occur among same-sex or heterosexual or transgender couples. Behaviors include rape, physical assault, harassment, destruction of property, and stalking." Janet Mickish, Domestic Violence: "Make It Your Business" A Huge Success, 33 Colo. Law. 49 (Dec. 2004).

80. Between 1 and 4 million women experience a serious assault by an intimate partner (of either sex) each year. American Bar Association, Commission on Domestic Violence Statistics, http://www.abanet.org/domviol/ stats.html (last visited Aug. 14, 2005) [hereinafter ABA Domestic Violence Statistics]. Nearly 835,000 men are victims of domestic violence (inflicted by a partner of either sex) annually. Patricia Tjaden \& Nancy Thoennes, Prevalence, Incidence, and Consequences of Violence Against Women: Findings From the National Violence Against Women Survey, National Institute of Justice (Nov. 1998), at http://ncjrs.org/txtfiles/172837.txt (last visited July 8, 2005) [hereinafter NVAW Survey Findings]. IPV is the primary source of injury to women in the United States, "causing more injuries than rapes, auto accidents, and muggings combined." Tonya McCormick, Note and Comment, Convicting Domestic Violence Abusers When the Victim Remains Silent, 13 BYU J. PUB. L. 427, 429 (1999) (citing NOW Legal Defense and Education Fund, Domestic Violence Fact Sheet (1995)). Another statistical perspective reveals that IPV accounts for $28 \%$ of all violence against women and $5 \%$ of all violence against men. ABA Domestic Violence Statistics, supra. IPV crosses ethnic, racial, age, national origin, religious, and socioeconomic lines. Id. Same-sex battering occurs at roughly the same rate as opposite-sex battering. Id. On the difficulties in defining the etiology of domestic violence, see Daniel Sonkin \& Douglas Liebert, The Assessment of Court-Mandated Perpetrators of Domestic Violence, 6(2) J. AGgression, MaLTREATMENT AND Trauma 3 (2003).

81. See ABA Domestic Violence Statistics, supra note 80. See also Margi LaIRD McCue, Domestic Violence: A Reference HandBook 113 (1995) (reporting a study which found a 50\% chance that a battered woman who separates from her partner will slip below the poverty line); Peter Margulies, Representation of Domestic Violence Survivors as a New Paradigm of Poverty Law: In Search of Access, Connection, and Voice, 63 GEo. WASH. L. REv. 1071, 1076 (1995) (reporting an estimate that half of homeless women lack housing due to domestic violence).

82. ABA Domestic Violence Statistics, supra note 80; see also Mary Ann Dutton \& Lisa A. Goodman, Posttraumatic Stress Disorder Among Battered Women: Analysis of Legal Implications, 12 BeHAv. Scr. \& L. 215, 219 (1994).

83. See, e.g., Linda L. Baker \& Peter G. Jaffe, Centre for Children and Families in the Justice SysTem, Youth Exposed to Domestic Violence 2 (2003) (indicating that domestic violence "is part of a constellation of risk factors linked to poor outcomes in youth, such as later victimization, violent behavior and other 
delinquent behaviors") (citations omitted); Marjory D. Fields, The Impact of Spouse Abuse on Children and Its Relevance in Custody and Visitation Decisions in New York State, 3 Cornell J.L. \& Pub. Pol'y 221, 222-34 (1994) (exploring the correlation between spouse abuse and child abuse and the emotional and psychological harm caused to children by domestic violence).

84. See, e.g., Nicole Howland, The Landscape of Domestic Violence in South Carolina, 16 S.C. Law. 40, 4243 (Nov. 2004) (highlighting the impact of actual or potential criminal prosecution on related family court matters and discussing legal ethics quandaries).

85. Joan S. Meier, Notes from the Underground: Integrating Psychological and Legal Perspectives on Domestic Violence in Theory and Practice, 21 Hofstra L. Rev. 1295, 1297 (1993).

86. American Bar Association, Commission on Domestic Violence, Section of Family Law, Report to the House of Delegates, at 3 (Aug. 2003), at http://www.abanet.org/crimjust/policy/am03120.pdf (last visited June 21, 2005) [hereinafter ABA Domestic Violence Report]; see also Deborah Goelman \& Roberta Valente, When Will They Ever Learn? Educating to End Domestic Violence: A LaW School Report 1 (American Bar Association, Commission on Domestic Violence, 1997) ("It is startling how many lawyers do not know what the legal definition of domestic violence is or what abusive behaviors are covered by the law.").

87. See, e.g., New York State Office for the Prevention of Domestic Violence, Medical and Legal Protocol for Dealing with Victims of Domestic Violence, at http://www.opdv.state.ny.us/health_humsvc/health/protocol/ identification.html (last visited July 9, 2005). (Patients receiving care in the emergency department, and surgical, primary care, pediatric, prenatal, substance abuse, and mental health settings should be informed that "[b]ecause intimate partner violence and abuse are so common, we screen for it routinely.") (Emphasis in original).

88. See, e.g., Lisae C. Jordan, Secure Safety First: A Domestic Violence Screening Checklist, 27 Fam. AdvoCATE 10 (Spring 2005) (supplying cues for lawyers to detect when their clients are victims of domestic violence); Kathleen Finley Duthu, Why Do You Need to Know about Domestic Violence? How Attorneys Can Recognize and Address the Problem, 53 LA. B.J. 20, 20-22 (June/July 2005); ABA Commission on Domestic Violence, The Impact of Domestic Violence on Your Legal Practice: A LaWyer's Handbook (2d ed. 2004) (providing an overview of the legal aspects of domestic violence, intended to aid attorneys in representing clients responsibly by helping them recognize domestic violence and its possible impact on a legal matter).

89. ABA Domestic Violence Report, supra note 86, at 3.

90. See Naomi Cahn \& Joan Meier, Domestic Violence and Feminist Jurisprudence: Towards a New Agenda, 4 B.U. Pub. InT. L.J. 339, 348 (1995).

91. Symposium, Domestic Violence in Legal Education and Legal Practice: A Dialogue Between Professors and Practitioners, 11 J.L. \& PoL'y 409, 414 (2003) (quoting remarks of Candace Sady). See also Sarah M. Buel, A Lawyer's Understanding of Domestic Violence, 62 Tex. B.J. 936, 937 (1999) ("Despite the overwhelming presence of domestic violence in our communities, and the documented case mismanagement, there is neither a systematic nor comprehensive approach to teaching the subject in our law schools or continuing legal education programs").

92. ABA Domestic Violence Report, supra note 86, at 7. See also Goelman \& VAlente, supra note 86 (advocating that law schools teach the legal issues surrounding domestic violence).

93. Child maltreatment is the general term used to describe all forms of child abuse and neglect. National Association of Counsel for Children, Child Maltreatment, at http://naccchildlaw.org/childrenlaw/childmaltreatment.html (last visited July 10, 2005) [hereinafter Child Maltreatment]. The federal Child Abuse Prevention and Treatment Act defines child abuse and neglect as "the physical and mental injury, sexual abuse, negligent treatment, or maltreatment of a child under the age of 18 by a person who is responsible for the child's welfare under circumstances which indicate that the child's health or welfare is harmed or threatened." Child Abuse Prevention and Treatment Act, as amended by Keeping Children and Families Safe Act of 2003, 42 U.S.C. $§ 5106(\mathrm{~g})$.

94. U.S. Department of Health and Human Services, Administration for Children \& Families, Child Maltreatment 2003: Reports from the States to the National Child Abuse and Neglect Data Systems - National Statistics on Child Abuse and Neglect (2003), at http://www.acf.hhs.gov/programs/cb/pubs/cm03/summary.htm (last visited May 18, 2006).

95. See Jay Belsky, Etiology of Child Maltreatment: A Developmental-Ecological Analysis, 114 No. 3 PsycHOL. BuLL. 413 (1993). ("[T]here not only appears to be no single cause of child maltreatment, but no necessary or sufficient causes. All too sadly, there are many pathways to child abuse and neglect").

96. See Barbara Bennett Woodhouse, "Who Owns the Child?": Meyer and Pierce and the Child as Property, 33 WM. \& MARY L. REV. 995, 1037 (1992) (noting the enormous power of the colonial era father over his household).

97. Child Maltreatment, supra note 93; see id. (noting the critical importance of the identification of the Battered Child Syndrome in the 1960s). The work of C. Henry Kempe pushed medical professionals to admit that 
significant numbers of parents and caretakers batter their children, even to death. C. Henry Kempe et al., The Battered-Child Syndrome, 181 JAMA 17 (1962) (defining the term as a clinical condition in young children who have received serious physical abuse, generally from a parent or foster parent).

98. See Kristi Baldwin, Battered Child Syndrome as a Sword and a Shield, 29 Am. J. CRIM. L. 59, 63-64 (2001) (describing the use of psychological data to identify emotional effects suffered by children with the syndrome); Steven R. Hicks, Admissibility of Expert Testimony on the Psychology of the Battered Child, 11 LaW \& Psychol. Rev. 103, 108-11 (1987) (noting that Battered Child Syndrome has come to describe both the physiological and psychological effects of a prolonged pattern of physical, emotional, and sexual abuse).

99. See, e.g., Susan C. Smith, Abused Children Who Kill Abusive Parents: Moving Toward an Appropriate Legal Response, 42 CATH. U. L. Rev. 141, 141 (1992) (citations omitted):

Child abuse is an inordinately complex problem in the United States. . . For those children able to survive the abuse, research reveals that they are likely to suffer serious physical injuries, emotional trauma, or become future victims of abuse or perpetrators of violence against others.

Id.

100. Justine A. Dunlap, Sometimes I Feel Like a Motherless Child: The Error of Pursuing Battered Mothers for Failure to Protect, 50 Loy. L. Rev. 565, 568 (2004).

101. Jeffrey L. Edleson, The Overlap Between Child Maltreatment and Woman Abuse (rev. Apr. 1999), at 2, at http://www.vawnet.org/DomesticViolence/Research/VAWnetDocs/AR_overlap.php. See also GoELMAN \& VALENTE, supra note 86, at 26 (footnote omitted):

Frequently, perpetrators [of intimate partner violence] use the children to manipulate victims: by harming or abducting the children; by threatening to harm or abduct the children; by forcing the children to participate in abuse of the victim; by using visitation as an occasion to harass or monitor victims; or by fighting protracted custody battles to punish victims. Perpetrators often invent complex rules about what victims or the children can or cannot do, and force victims to abide by these frequently changing rules.

Id.

102. See http://www.abanet.org/child/childrep.html (last visited July 11, 2005).

103. Suellyn Scarnecchia, An Interdisciplinary Seminar in Child Abuse and Neglect with a Focus on Child Protection Practice, 31 U. Mich. J.L. Reform 33, 33-34 (1997) (citations omitted).

104. Jennifer R. Gavin, Child Welfare Law Curricula in Legal Education: Massachusetts' Untried Opportunity, 7 B.U. Pub. InT. L.J. 9, 10 (1998); see David B. Mitchell, Building a Multidisciplinary, Collaborative Child Protection System: The Challenge to Law Schools, 41 FAm. CT. REv. 432, 435 (2003):

$[\mathrm{O}]$ nly a handful of [law] schools provided their students training in juvenile law that exceeded the survey level of instruction. Few institutions provide in-depth training in the legal issues of delinquency and child dependency matters or involve other disciplines in the course of the training of future lawyers. Id.

105. Victor I. Vieth, The National Child Protection Training Center: A Partnership Between APRI and Winona State University, 38 Prosecutor 33, 33 (Jan./Feb. 2004).

106. It is not surprising that this issue did not come up in the discussions where custody evaluators, mediators, and others played a major role. Though some mediators mediate financial issues, the expertise of the non-lawyer participants in the FLER Project very much stressed custody and child access.

107. The Employee Retirement Income Security Act, 29 U.S.C. $§ 1001$ (2005), the main source of U.S. pension law.

108. Capital gains and losses are covered in Subchapter P of the Internal Revenue Code. See 26 U.S.C. $\S \S$ 1201-1298.

109. Temporary Assistance to Needy Families. In 1996, Congress passed the Personal Responsibility and Work Opportunity Reconciliation Act of 1996, Pub. L. No. 104-193, 110 Stat. 2105, abolishing the Aid to Families with Dependent Children program, which had been in effect, in one form or another, since the creation of the Social Security system in 1935 .

110. The acronym comes from the Consolidated Omnibus Budget Reconciliation Act. COBRA has long been a vehicle for providing health insurance continuation when the insured person's link to a providing employer is severed. The COBRA provisions relevant to health insurance continuation are codified at 29 U.S.C. $\S \S 1161-1169$.

111. As with much of what we outline in this Report, there are nearly endless ways to achieve this goal. For example, a professor might supplement Loving v. Virginia, 388 U.S. 1 (1967), the U.S. Supreme Court decision striking down the anti-miscegenation law of the State of Virginia, with readings about the civil rights movement. Or a professor could assign feminist readings and consider the impact of the feminist movement or of women's increasing opportunities in the labor force on no-fault divorce. The goal is to persuade students that events in the larger culture shape the law and that being aware of them is an essential part of the lawyer's task. 
112. Again, there are myriad possibilities: the Bush administration's marriage promotion campaign, the plight of families made up of U.S. citizens and illegal aliens post 9/11, the influence of the Christian right on covenant marriage, the gay rights movement and same-sex marriage, the adoptees' "right to know" movement and the unsealing of adoption records.

113. Bounds of Advocacy, supra note 53, at 1 .

114. Id. at 2 (noting that the emphasis on zealous representation of individual clients in criminal and some civil cases is not always appropriate in family law matters).

115. See American Bar Association, Model Rules of Professional Conduct, at http://www.abanet.org/cpr/mrpc/ mrpc_home.html (last visited July 14, 2005).

116. See http://www.abanet.org/cpr/profcodes.html (last visited July 14, 2005) (listing professionalism codes).

117. Churning occurs when a lawyer, exercising control over the volume, frequency, and formality of events, abuses his/her power for personal gain by rendering professional services that are excessive in view of the nature and character of the matter. Los Angeles County Bar Association Professionalism Guidelines for Family Law Practitioners, at http://www.law.stetson.edu/excellence/litethics/lacobarfam.htm (last visited July 14, 2005) [hereinafter Los Angeles Professionalism Guidelines].

118. An attorney engages in economic coercion when he or she conducts the proceeding "so as to cause unnecessary and unreasonable expense to be borne by the adverse party, or to cause unnecessary delay, for the purpose of coercing a resolution favorable to the attorney's client." Id.

119. Vindictive litigation occurs when a client's primary goal is to harm the adverse party. The client's emotional state may be such that he or she is willing to dissipate a substantial portion or all of the family's resources on attorney's fees. $I d$. The guidelines also proscribe personal attacks on opposing counsel, and mandate avoidance of "personal derogatory comments about the other party." Id.

120. See MacCrate Report, supra note 26, at 138-40.

121. Id. at 140 .

122. See generally Louis Parley, The Ethical Family Lawyer: A Practical Guide to Avoiding ProFessional Dilemmas (1995) (surveying the field). Ethics guidelines for lawyers now extend to their relationships with other professionals. For example, the Los Angeles Professionalism Guidelines state that family lawyers should not participate in ex parte communications with child custody evaluators or court-appointed expert witnesses and that they should promptly disclose any social, financial, or professional relationship with a child custody evaluator. Los Angeles Professionalism Guidelines, supra note 117.

123. See, e.g., Bounds of Advocacy, supra note 53 (Sec. $7.1 \mathrm{cmt}$.: Some clients expect and want the matrimonial lawyer to reflect the highly emotional, vengeful relationship between the spouses. The attorney should explain to the client that discourteous or uncivil conduct is inappropriate and counterproductive, that measures of respect are consistent with competent and ethical representation of the client, and that it is unprofessional for the attorney to act otherwise.).

124. Los Angeles Professionalism Guidelines, supra note 117.

125. See Jeremy M. Miller, Legal Ethics and Classroom Teaching: The Apology, 14 WIDENER L.J. 365, 371 (2005) (contending that law professors impact their students' ethics both as students and, ultimately, as lawyers); Jean M. Cary, Rambo Depositions: Controlling an Ethical Cancer in Civil Litigation, 25 Hofstra L. Rev. 561, 600 (1996) (arguing that Rambo behavior should be discussed and condemned in law schools).

126. Many studies document a quite negative view of the family law process by its consumers. See, e.g., Pruett \& Jackson, supra note 58, at 294 (reporting that divorcing parents expressed disappointment, disillusionment, and frustration that permeated all aspects of the divorce process, from perceptions of the overall legal system to specific attributes of their attorneys); SCHEPARD, supra note 34, at 42-43 (citing UNITED States Commission on Child and Family Welfare, Parenting Our Children: In the Best Interests of the Nation: A Report to the President and Congress (1996), finding that $50 \%$ to $70 \%$ of parents described the adversarial system as "impersonal, intimidating, and intrusive"); Ronald E. MALLEN \& JEFFREY M. Smith, Legal Malpractice $§ 22.2$, at 330-33 (3d ed. 1989) (citing statistics collected by ABA's National Legal Malpractice Data Center indicating that "family law practitioners account for a significant percentage of all claims ... Client relationship errors are much greater than the average, the highest of all reported areas of law").

127. Rambo lawyering may be characterized by the following:

A mindset that litigation is war and that describes trial practice in military terms. A conviction that it is invariably in your interest to make life miserable for your opponent. A disdain for common courtesy and civility, assuming that they ill befit the true warrior. A wondrous facility for manipulating facts and engaging in revisionist history. A hair-trigger willingness to fire off unnecessary motions and to use discovery for intimidation rather than fact-finding. An urge to put the trial lawyer on center stage rather than the client or his cause. 
Robert N. Sayler, Rambo Litigation: Why Hardball Tactics Don't Work, 74 A.B.A. J. 78,79 (1988). See also Gideon Kanner, Welcome Home Rambo: High-Minded Ethics and Low-Down Tactics in the Courts, 25 Loy. L.A. L. REV. 81, 81 n.2 (1991) (equating Rambo litigation tactics with Godzilla litigation).

128. See Andrea Kupfer Schneider, Shattering Negotiation Myths: Empirical Evidence on the Effectiveness of Negotiation Style, 7 Harv. Negot. L. Rev. 143, 196-97 (2002) (setting forth study results showing that ethical lawyers who are problem-solving negotiators are the most effective); Sayler, supra note 127 (contending that hardball litigators are both unsuccessful and disrespected).

129. An intriguing study of lawyer competence is currently being conducted by Professors Marjorie Shultz and Sheldon Zedeck. In the first phase of their study, Professors Shultz and Zedeck collected data from over 2,000 participants (judges, clients, students, litigators). The researchers created a 26 -factor inventory of skills and abilities. Their ongoing study can be viewed at http://www.law.berkeley.edu/alumni/transcript/summer_05/2227_feat_23_lsat_final.pdf.

130. When asked to select skills that were extremely important for lawyers, $96.4 \%$ of respondents selected listening. By contrast, $41.3 \%$ selected courtroom advocacy and $28.4 \%$ writing persuasive papers. See supra note 14 , (describing the FLER Project survey).

131. See, e.g., Ithaca College Dept. of Sociology, at http://departments.ithaca.edu/sociology/catalog/ (last visited Oct. 10, 2005). Describing the concentration in Clinical Sociology, the catalog states that "[c]ourses in this concentration help students examine the relation between 'personal problems' and the larger societal structure. Students learn about theories behind counseling, intervention strategies, effective listening skills, and helping relationships." See also University of Iowa, National Resource Center for Family Centered Practice, Family Development Specialist Certification Training, listing "participants will demonstrate active listening skills" as an outcome of this program, at http://www.uiowa.edu/ nrcfcp/training/certification.shtml (last visited Oct. 10, 2005).

132. See, e.g., Gary Skoloff \& Robert J. Levy, Custody Doctrines and Custody Practice: A Divorce Practitioner's View, 36 FAM. L.Q. 79, 98 (2002):

Few divorce lawyers are or can be therapists for their clients, but none of them can successfully arrange divorces for clients without becoming empathic and sophisticated listeners, successful communicators, and effective translators of clients' emotions. Good lawyers deal with their divorce clients' emotions because they know that unless emotions are confronted and become an aspect of the lawyer-client transaction, emotions will interfere with and may undermine successful outcomes . . . Clients' emotions, their fear, their anger and vulnerability, distort communication, obstruct prediction and paralyze planning - for divorce and for their clients' future.

Id.

133. California was the first U.S. state to adopt modern no-fault divorce legislation. Family Law Act of 1969 , codified at CAL. CIV. CoDE $\S 4350$ et seq. Extensive study preceded the statute's adoption, culminating in the 1966 Report of the Governor's Commission on the Family. Commenting on the shortcomings of fault divorce, the Report states:

The Commission has taken as its principal duty the development of a system of judicial procedure which will deal with the troubles of the family in a comprehensive way, and which will, insofar as possible, reduce the friction and destructive hostility which are engendered by the present adversary process and the concept of fault as a determinant of divorce and its consequences.

REPORT OF THE GOVERNOR's COMMISSION ON THE FAMILY 33 (1966).

134. See Mary E. O'Connell, Alimony After No-Fault: A Practice in Search of a Theory, 23 New Eng. L. REv. 437, 492 (1988).

135. For an excellent, brief discussion of the shift from fault to no-fault, see CARL E. SCHNEIDER \& MARGARET F. Brinig, An Invitation to Family Law: Principles, Process and Perspectives 89-115 (2d ed. 1995).

136. See, e.g., Mass. GEN. Laws ch. $208 \S 34$ (West 2005) (Courts reviewing a divorcing spouse's request for alimony should consider, among other things, the conduct of the parties during the marriage.).

137. Writing in 1985, 15 years after the no-fault divorce statute was adopted in California, sociologist Lenore Weitzman noted the anger and fear, particularly of older divorcing spouses. See Lenore J. Weitzman, The Divorce Revolution: The Unexpected Social and Economic Consequences for Women and Children IN AMERICA 20-21 (1985).

138. In a number of jurisdictions, attorneys are required to inform their clients about the availability of mediation. See discussion and a list of states (California, Colorado, Hawaii, Massachusetts, Michigan, and Virginia) in Gerald F. Phillips, The Obligation of Attorneys to Inform Clients about ADR Mediation-A Win-Win Process: "Try It, You'll Like It”, 31 W. St. U. L. Rev. 239, 246-52 (2004).

139. This may rise to the level of collaborative law, see TESLER, supra note 21, or it may be a less structured form of representation that nonetheless involves a team or coalition building. 
140. Note, for example, that mediation of at least some issues is mandated in several states and that courts may appoint guardians ad litem or other experts. See, e.g., CAL. FAM. Code $\S 3170$ (West 2005) (requiring pre-hearing mediation of child custody and visitation disputes, but not of disputes involving support); see also Standing Orders of the Probate and Family Court of Massachusetts, 4 S.O. 1-05, Standards for Category F, Guardians ad Litem/Investigators in actions involving: Domestic Relations or Custody/Visitation/ Adoption.

141. Of course, this does not mean that no such discussion has ever occurred, only that none of the more than 20 law professors who participated intensely in the project mentioned leading or participating in such a discussion.

142. Again, in some jurisdictions, there will be a statutory requirement or court rule mandating that the attorney discuss mediation with all clients, at least in divorce cases. See supra note 140.

143. See, e.g., University of New Mexico Law School, at http://lawschool.unm.edu/curriculum/upperclass/ descriptions/ (last visited Sept. 20, 2005); see also University of Denver Sturm College of Law, at http:// www.law.du.edu/msla/courses.htm (last visited Sept. 20, 2005); University of Baltimore School of Law, at http:// law.ubalt.edu/courses/lawfirm.html (last visited Sept. 20, 2005); William \& Mary Marshall-Wythe School of Law, at http://www.wm.edu/law/academicprograms/curriculum/electives/law498-01.shtml (last visited Sept. 20, 2005).

144. See Section III (D)(1)(c) above on Setting Boundaries with Clients.

145. See http://professionalism.law.sc.edu/materials/nurturequality.html (last visited Aug. 16, 2005) (listing resources aimed at coping with stress, nurturing a lawyer's quality of life, and balancing work and play). It is not surprising that attorneys' difficulties in counseling clients who are experiencing difficult personal and emotional issues are linked to the lack of lawyer self-care. See Judith L. Maute, Balanced Lives in a Stressful Profession: An Impossible Dream?, 21 CAP. U. L. Rev. 797, 798-99 (1992):

[Lawyers] frequently insulate themselves from emotional matters with clients, associates, and family. Safely sheltered in their legal cocoons, they have little comprehension of their client's ultimate concerns with the legal problem at hand. Such lawyers are not bad people; they do not consciously ignore clients' expressed wishes. Rather, they have so insulated themselves from the concerns of ordinary laypersons that they simply do not detect when a client may have objectives beyond the standardized outcome the lawyer imputes to the client. They seldom grasp the trauma and personal effects of their clients' legal problems. What causes this gap in understanding? I suggest that excessive work demands, with inordinate focus on the rational, task-oriented nature of most lawyering skills, distort lawyers' perceptions of reality, and what is important to the clients they serve. I submit that lawyers who are whole persons with balanced lives can better provide competent services appropriate for their clients' needs and concerns.

Id.

146. See, e.g., 33 Monitor on Psychol. 7 (July/Aug. 2002). A description is available at http://www.apa.org/ monitor/julaug02/selfcaretoc.html. As another example, the social work program at Walla Walla College includes courses on personal stress management (SOWK 578). See http://www.wwc.edu/1010.o.html.

147. In 1966, 4\% of law students in the United States were women; since the year 2000, women and men have attended law schools in virtually equal numbers. See Louise B. Raggio, Women Lawyers in Family Law, 33 FAM. L.Q. 501, 507 (1999); Ronit Dinovitzer et Al., After the JD: First Results of a National Study of LEGAL CAREERS 57 (2004), available at http://www.nalpfoundation.org/webmodules/articles/articlefiles/87After_JD_2004_web.pdf. Numerical parity for beginning lawyers should not, of course, be confused with professional equality. See Joanna Grossman, The New ABA Report on Women and Law: Why the Solutions the Report Proposes May Not Work in the Real World, at http://writ.news.findlaw.com/grossman/20010522.html (last visited Aug. 16, 2005) (summarizing an ABA Report's conclusions that women lawyers continue to be undercompensated, undervalued, sexually harassed, and victimized by discrimination and bias).

148. DinOVITZER ET AL., supra note 147. Of course, there are other explanations for the gender disparity in family law as well. See, e.g., Raggio, supra note 147, at 512 (arguing that women lawyers gravitated to family law because they wanted to focus on laws concerning child welfare, rights of women, family violence, marriage and divorce, education, and other things of interest to the family). Today, women lawyers make up a disproportionate share of the family law bar. A recent statewide bar survey in New Hampshire indicated that domestic relations continues to be the most common legal specialty for women lawyers, with $22 \%$ of all female lawyers, but only $6 \%$ of males, spending $50 \%$ or more of their time practicing family law. WOMEN IN THE WORLD's LEGAL Professions 35-36 (Ulrike Schultz \& Gisela Shaw eds., 2003). Not surprisingly, female law professors teach family law in higher percentages than their male colleagues. For example, in 1999-2000, women constituted $31.5 \%$ of all law school faculty, but $58 \%$ of the faculty teaching family law. Association of American Law Schools, The AALS Directory of Law Teachers 1999-2000, at 1155-59 (1999).

149. Further development of joint-degree programs pairing law with psychology, social work, and related fields was also encouraged by FLER Project participants. 
150. See LSAC Cautionary Policies Concerning LSAT, at http://www.lsacnet.org/publications/ CAUTIONARYPolicies.pdf (last visited Sept. 20, 2005) ("LSAT scores provide a standard measure of an applicant's proficiency in the well-defined set of skills included in the test.").

151. See Melissa Breger et al., Building Pediatric Law Careers: The University of Michigan Law School Experience, 34 FAM. L.Q. 531, 532-33 (2000) ("The greatest obstacle to developing the careers of pediatric lawyers is the low pay and low prestige typically afforded children's lawyers. As a result, law students reasonably question the likelihood of developing a successful career in the field. The number of available jobs is limited and pediatric lawyers can rarely spend significant time or money on training or other educational resources").

An irony should be mentioned in connection with family law's low prestige. Measured by court filings, family law is the fastest-growing legal field, and one quarter of all pleadings filed in state courts make a family law claim. Andrew Schepard, Law Schools and Family Court Reform, 40 FAм. Cт. ReV. 460, 460 (2002). It seems odd that the most capacious field of law needs to advertise. See Hasday, supra note 28, at 828 n.4 ("[T]he low status of family law is puzzling, given the sheer volume of family law cases, the importance of family law in structuring people's lives ... and the goods (monetary and psychological) at stake"). Given the pro se explosion, a sizable number of these cases are not being handled by lawyers. However, in light of the importance of the family law field, its continuing status woes merit further exploration.

152. See http://www.law.umich.edu/CentersAnd Programs/clinical/calc/summerfellowship.htm (last visited July 15, 2005) (describing program).

153. See http://www.hofstra.edu/Academics/Law/law_child_fellowship.cfm (last visited July 15, 2005) (describing program).

154. See http://luc.edu/law/academics/special/center/child_family.shtml (last visited Sept. 27, 2005) (describing program).

155. Robert A. Stein, The Future of Legal Education, 75 MinN. L. Rev. 945, 959 (1991).

156. MacCrate Report, supra note 26. See also Linda R. Crane, Interdisciplinary Combined-Degree and Graduate Law Degree Programs: History and Trends, 33 J. Marshall L. Rev. 47, 53 (1999) (describing the notion of greater legal specialization as "axiomatic").

157. Jeffrey E. Lewis, “Advanced” Legal Education in the Twenty-First Century: A Prediction of Change, 31 U. ToL. L. ReV. 655, 656 (2000).

158. FLER Project participants also strongly endorsed the notion that skill building must continue after law school and that lawyers should be encouraged to join and participate in multidisciplinary professional organizations. Many of these organizations have student memberships, allowing the early development of professional contacts. See, e.g., American Psychology-Law Society, at http://www.ap-ls.org (last visited Aug. 16, 2005); National Association for Community Mediation, at http://www.nafcm.org (last visited Aug. 16, 2005); American Economic Association, at http://www.vanderbilt.edu/AEA/mbr.htm (last visited Aug. 16, 2005).

159. See http://www.law.buffalo.edu/family_law/ (last visited July 11, 2005) [hereinafter UB Program for Excellence in Family Law].

160. Id.

161. Northeastern's unique cooperative legal education program requires all students to complete four 3-month periods of full-time legal placement prior to graduation. Students interested in family law or legal issues affecting children can clerk in a family or juvenile court for 3 months; work at any of five child advocacy centers in three different states; work with prosecutors in specialized child abuse prosecution units; or work for a state social service agency, for the family law unit of a legal services office, for a private practitioner specializing in family law issues, or in other family or child-related placements.

Two other innovative programs are located at Yeshiva University's Cardozo School of Law and at Capital University Law School. Cardozo's Program in Family Law, Policy, and Bioethics allows students to earn a concentration in family law and participate in the Family Court Clinic and the Mediation Clinic. See http:// www.cardozo.yu.edu/familylaw/Opportunities_in_Family_Law.asp (last visited July 11, 2005). Capital University's Children and Family Law concentration allows students to gain experience in standard family law practice areas such as divorce and child custody, and also more specialized areas such as juvenile justice, adoption law, school law, elder law, and sexual orientation and the law. The Children and Family Law concentration is linked with the law school's National Center for Adoption Law and Policy and its Family Advocacy Clinic. See http:// www.law.capital.edu/Academic/ChilFam.asp (last visited July 11, 2005).

Certification programs are also available outside of the law schools. A prominent example is the National Association of Counsel for Children's Child Welfare Attorney Certification program. See http://naccchildlaw.org/ training/certification.html.

162. Austin D. Sarat \& William L. F. Felstiner, Divorce Lawyers and Their Clients: Power and Meaning in the Legal Process (1995). 
Mary E. O'Connell is Professor of Law at Northeastern University School of Law, where she has served on the faculty for more than 20 years. Professor O'Connell's research has focused on the well-being of American families and the effects of legal and social change on family welfare. She has been involved in a long-term collaboration with the Child and Family Forensic Center of the University of Massachusetts Medical School, where she regularly serves as a guest presenter. She is also the founder of the Northeastern Law School Youth Advocacy Caucus, which provides mentoring for two dozen teenagers in state custody.

J. Herbie DiFonzo is Professor of Law at Hofstra University, where he also directs the LL.M. Program in Family Law. Professor DiFonzo had a wide-ranging 17 years of law practice before becoming a full-time professor, including terms as an Assistant U.S. Attorney in the District of Columbia and in the Eastern District of Virginia. He then practiced as a litigator in the areas of criminal defense, family law, and professional malpractice. In all, he conducted over 30 jury trials and several dozen appeals. He has published broadly on the intersection of family law and juvenile justice. In 2005, he gave the Hofstra University Distinguished Faculty Lecture and, in 2004, he gave the Peter E. Herman Prize for Literary Excellence Lecture. He has published the widely acclaimed Beneath the Fault Line: The Popular and Legal Culture of Divorce in Twentieth-Century America. His most recent articles include "The Crimes of Crime Labs," "In Praise of Statutes of Limitations in Sex Offense Cases," "Unbundling Marriage," "Legislating in the Shadow of Nature," and "Toward a Unified Field Theory of the Family." 
Copyright of Family Court Review is the property of Blackwell Publishing Limited and its content may not be copied or emailed to multiple sites or posted to a listserv without the copyright holder's express written permission. However, users may print, download, or email articles for individual use. 